\title{
Effects of Climate Change and Flow Regulation on the Flow Characteristics of a Low-Relief River within Southern Boreal Climate Area
}

\author{
Elina Kasvi ${ }^{1, *}$, Eliisa Lotsari ${ }^{1,2}$, Miia Kumpumäki ${ }^{3}$, Tanja Dubrovin ${ }^{3}$ and Noora Veijalainen ${ }^{3}$ \\ 1 Department of Geography and Geology, University of Turku, 20014 Turun Yliopisto, Finland \\ 2 Department of Geographical and Historical Studies, University of Eastern Finland, Yliopistokatu 2, \\ 80101 Joensuu, Finland \\ 3 Finnish Environment Institute, Latokartanonkaari 11, 00790 Helsinki, Finland \\ * Correspondence: elina.kasvi@utu.fi; Tel.: +358-504-077-293
}

Received: 18 June 2019; Accepted: 29 August 2019; Published: 2 September 2019

\begin{abstract}
We investigated how hydro-climatological changes would affect fluvial forces and inundated area during a typical high-flow situation (MHQ, mean high discharge), and how adaptive regulation could attenuate the climate change impacts in a low-relief river of the Southern Boreal climate area. We used hydrologically modeled data as input for 2D hydraulic modeling. Our results show that, even though the MHQ will increase in the future (2050-2079), the erosional power of the flow will decrease on the study area. This can be attributed to the change of timing in floods from spring to autumn and winter, when the sea levels during flood peaks is higher, causing backwater effect. Even though the mean depth will not increase notably (from $1.14 \mathrm{~m}$ to $1.25 \mathrm{~m}$ ) during MHQ, compared to the control period (1985-2014), the inundated area will expand by $15 \%$ due to the flat terrain. The increase in flooding may be restrained by adaptive regulations: strategies favoring ecologically sustainable and recreationally desirable lake water levels were modeled. The demands of environment, society, and hydropower are not necessarily contradictory in terms of climate change adaptation, and regulation could provide an adaptive practice in the areas of increased flooding.
\end{abstract}

Keywords: climate change; stream erosion; flood risk; hydraulic modeling; regulated rivers

\section{Introduction}

Approximately two third of the world's fresh water flowing into the oceans is obstructed by dams [1-3]. Flow regulation directly and indirectly affects the ecosystem structures and processes, as well as the human watershed activity. Usually regulation causes less variable flows in the rivers downstream and increasing fluctuation of water levels in the reservoirs behind the dams [2,4]. Channel erosion and ecosystem impacts resulting from sediment starvation have been recorded downstream of dams [5-12]. The water volume increase upstream of a dam may cause inundation of terrestrial and riparian areas, affecting the riparian ecosystems $[2,9,13]$.

Downstream of a dam, the flood peaks and the frequency of overbank flooding as well as the groundwater formation are reduced [3]. This may hinder channel development, and reduce geomorphologic and floodplain productivity [13]. Low-altitude areas are generally more sensitive to water regulation than high-altitude areas because the terrain is flatter and small alterations in flow may affect vast areas [3]. In the Southern Boreal climate area, flow regulation may increase winter stream flow and temperatures, reduce ice formation and surface ice cover downstream of power plant [14], and thereby increase ice dam formation probability [5,15].

Climate change is expected to alter hydrological cycle and affect hydropower generation with fluctuations in power generation capacity projected in different parts of the world [16,17]. 
Seasonal changes can be significant in snow-dominated regions [18]. With changes in discharge and snowmelt conditions, climate change may also affect the transport of suspended sediments and change the intensity of erosion $[19,20]$. However, the uncertainties involved with different emission scenarios, climate models and hydrological models remain large [21-23]. The projected impacts of climate change on hydrology are non-uniform, even within relatively small regions, such as Finland, where the hydrological conditions and watershed properties are variable [24]. Along with hydrological changes, the shoreline shift caused by isostatic land uplift and the global mean sea level rise may affect the fluvial processes on the coastal sections of many river estuaries in northern Europe [25-27].

In Finland and many other countries, the discharge regimes of regulated rivers are controlled by regulation rules aiming to determine limits considered sustainable for the surrounding environment and human activity. However, ecosystems, people, and energy production may have conflicting interests, and the regulation standards must compromise between these [13,28-30]. The expected changes in hydro-climatological conditions and their seasonality, as well as both the land and sea level uplift, will evidently control the geomorphic effects of the flow processes and hydropower. Therefore, new regulation standards should be considered as a part of the adaptation to climate change [29,31]. The adaptive regulation standards, along with the hydro-climatological changes, will impact the sedimentation and erosion potential, as well as flood risk and the ecological status of the river and its estuary.

The exact nature of the future changes in various environments affected by flow regulation, as well as their magnitude and frequency, have not been studied well enough [2,32]. Previous studies have shown that the risks associated with climate change and water resource usage should be identified, and proactive management efforts could minimize risks to ecosystems and people and be less costly than reactive efforts taken only once problems have arisen [13,33]. Flow regulation could play an important role in the climate change adaptation of water resource availability, but attention is needed to mitigate the environmental and social impacts in the changing climate [16]. Therefore, it is essential to consider the local conditions (such as geographical, geological, topographical, and climatological conditions) when assessing climate change impacts. Global- and regional-scale studies on climate change impacts on hydrology by hydrological modeling have been performed widely [24,34-39], and the impact of climate change on river discharge and reservoir hydropower production has been studied, for example, in Alpine [40] and Arctic regions [41], as well as in northern countries [42-45]. However, studies investigating the co-effects of climate change and discharge regulation on the river morphology in low-altitude and low-relief, seasonally ice-covered areas, are lacking in the literature $[7,46,47]$. On those areas the fluvial and ice-related processes are expected to change due to climate change and they are also sensitive to water regulation due to the flat terrain.

In this study, we investigated how the predicted hydro-climatological changes would affect the distribution of fluvial forces and inundated area during typical high-flow situation (MHQ, mean high discharge), and how adaptive regulation standards could attenuate the climate change impacts in a low-relief river of the Southern Boreal climate area, Southwestern Finland. We investigated typical high flow events, because they repeat regularly and thus may have a great influence on the river morphology at long run [48-50]. We also acknowledge that adaptive regulation rules may be able to attenuate the climate change impact more in the case of more frequent flows. As initial data, we used hydrological scenarios on future hydro-climatology (2050-2079) and adaptive future regulation strategies, both produced by the Finnish Environment Institute [51]. Using a 2D computational fluid dynamics (CFD), we modeled MHQ flow situations during the reference period (1985-2014) and in the climate change period (2050-2079) with the current and adaptive regulation strategies. We compared the prevailing and future high flow conditions (inundated area, the flow depth, and the distribution of bed shear stress) and analyzed the effects of climate change and regulation on them. We discuss the possibilities of regulation in climate change adaptation considering societal and ecological aspects and hydropower production. 


\section{Study Area}

\subsection{Southern Boreal Climate Area and the Expected Hydro-Climatological Changes}

This study is located in Southwestern Finland, which belongs to the Southern Boreal climate area (Figure 1a). The climate is defined as cold but without a dry season and with warm summers [52]. The greatest flood peak is due to the spring snowmelt event, but already presently, the climatic change impacts are detectable, and the rain-induced autumn and early winter discharges have increased. The rivers are ice-covered annually, and frazil ice occurs [47].

In general, Northern Europe belongs to the area where climate change is expected to increase runoff and hydropower generation [22,53]. Earlier spring flows are also expected [24,44] and have already been observed $[54,55]$. Warming is projected to be substantially above the global average in this Southern Boreal region, a trend consistent with both model projections and observations, and the mean annual temperature is expected to increase $1.9-4.0^{\circ} \mathrm{C}$ by $2050-2079$, depending on the applied scenario [56,57]. This indicates a potential reduction in spring snowmelt discharges, a shift of the spring flood occurrence to earlier in the spring, and an increase in the magnitude and frequency of autumn/early winter discharges due to increased rain and zero-crossing events [24,31]. Depending on the used scenario, the annual precipitation is expected to increase $6-14 \%$ by $2050-2079$. The range of potential changes in temperature, precipitation and discharge are large due to differences in emission scenarios, climate models, hydrological models and natural variability $[21,23,58]$. Along with the increased future autumn and winter discharges (2070-2099), an increase in the exceeding of critical thresholds for incipient motion of sediment particles and a following increase in erosion potential have been forecasted in this region [59]. Because the majority of the scenarios project a similar direction of change, the average scenarios provide a representative image of the direction of the potential changes and their impacts on the river environments, as in this study [51]. However, the uncertainties in climate change projections should be taken into account when making conclusions from the results.

The anticipated relative sea level rise in the area differs from the global scenarios of sea level rise, which have been, according to the IPCC, $0.26-0.598 \mathrm{~m}$ by 2100 [60], due to the isostatic land uplift. Many coastal areas of Finland are currently experiencing a relative fall in sea level but they will be subject to a rising sea level in the future [25,61-63]. Based on the study by Pellikka et al. [63], the relative sea level change at the coast by the city of Pori will be on average $-13 \mathrm{~cm}$ by 2100 , because of the isostatic land uplift.

\subsection{General Description of the Study Area}

The study was performed in the lower reach ( $12 \mathrm{~km}$ long) of the Kokemäenjoki River in Southwestern Finland (Figure 1b). This is one of the outlet rivers from the lake area of Finland (Figure 1c). The river runs through the city of Pori (slightly below 85,000 inhabitants) in its estuary and drains into Pihlavanlahti Bay in the Gulf of Bothnia, Baltic Sea (Figure 1d). The estuary has branched into several narrow distributaries (fin. juopa). The main channel is $121 \mathrm{~km}$ long, and it has a watershed of $27,000 \mathrm{~km}^{2}$, making it the fourth largest in Finland. The lakes cover $11 \%$ of the watershed area, and many of the lakes and dams hold regulation possibilities [64,65] (Figure 1b). The discharge of the study area is controlled by various dams, the most downstream being the Harjavalta hydroelectric power plant. The discharge varies mostly between 70 and $400 \mathrm{~m}^{3} / \mathrm{s}$, with notable daily fluctuations due to short-term regulation. 


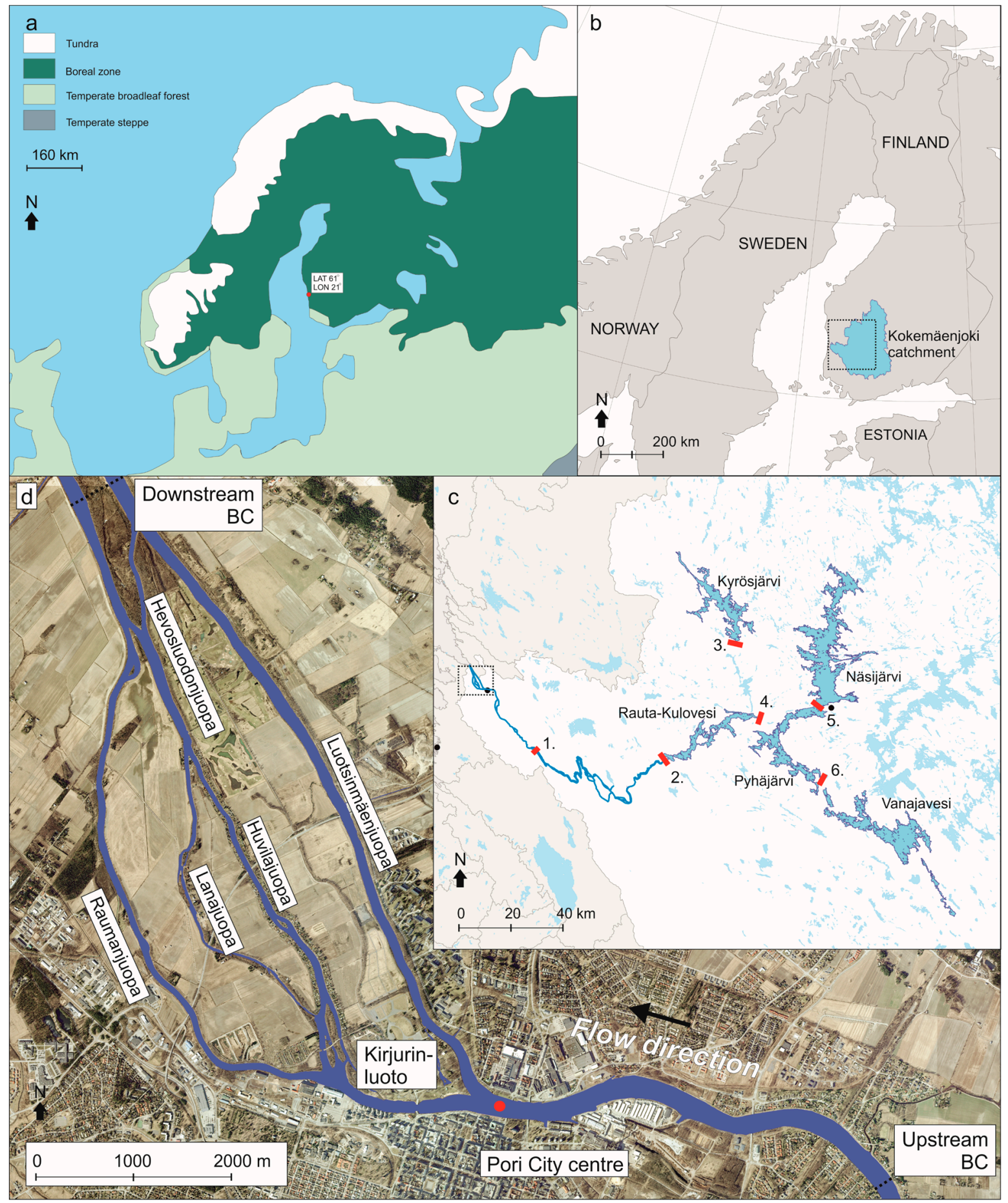

Figure 1. (a) The study area belongs to the Southern part of the boreal climate area. (b) The Kokemäenjoki watershed (27,000 square kilometers) is located in the South Western Finland and the river discharges into the Bothnian Bay, the Northern section of the Baltic Sea. (c) The lakes cover $11 \%$ of the watershed area. The main powerplants and dams controlling the discharge are numbered in the figure as follows: (1) Harjavalta dam; (2) Tyrvää dam; (3) Kyröskoski dam; (4) Melo dam; (5) Tammerkoski dam; and (6) Herralanvirta dam. (d) The downstream part of the river flows through Pori city center and is divided into several distributaries. The upstream and downstream boundaries of the hydraulic model are marked with dotted lines. The calibration point of the CFD is marked with a red dot. 
The river belongs to the South Boreal climate area [66]. The annual mean temperature is approximately $5{ }^{\circ} \mathrm{C}$, February being the coldest and July the warmest month with average temperatures of -5.4 and 16.8 degrees, respectively [67]. The mean temperature is under zero from December to March and the snow cover lasts typically from November to March. The annual precipitation is $\sim 600 \mathrm{~mm}$, August being the rainiest and April the driest month. Heavy rains in autumn and snow melt during late winter cause high discharges [24]. Together with backwater effect of the sea, frazil ice formation, and great sediment transport amounts [47,59], the Kokemäenjoki River and the city of Pori are one of the greatest flood hazard areas in Finland [68].

The bed material mainly consists of cohesive clay, silt, and fine sand [59]. Erosion dominates the lower Kokemäenjoki River but deposition is great at the Pori city center, where the main channel divides into the two main distributaries, Luotsinmäenjuopa and Raumanjuopa [59] (Figure 1c). However, again, in the Luotsinmäenjuopa and Raumanjuopa, erosion takes place due to the strong flow. In addition to the Pori city center, most of the sedimentation takes place in Pihlavanlahti Bay, with a deposition rate of $3 \mathrm{~cm} /$ year [69].

As in the Southern Boreal climate area in general, in the Kokemäenjoki watershed, the total runoff and inflows to the lakes are projected to increase in the future, despite the decreasing snowmelt-induced spring inflow peaks $[51,59,60]$. Additionally, the hydropower potential is expected to increase [51]. The timing of the springtime snowmelt peaks will be earlier than before, and a larger portion of precipitation will fall as rain. Summertime inflows to the lakes will decrease because of the earlier snowmelt and increase in evaporation during longer summer periods. These changes will also affect the river discharge. Wintertime discharge in the river will be on average larger than in the reference period, and the peak values will also increase. This has a direct impact on flood risks because an increase in discharge in the winter means more possibilities for frazil ice flood situations, which have already in the past caused most flood damage [51]. As a consequence of the hydro-climatological changes, the annual riverine sediment load will be redistributed within the seasons depending on the ice cover duration and applied climate scenario [47]. For example, the wintertime riverine sediment loads in the area are expected to double because of increased discharges by 2070-2099 [47]. However, adaptive actions such as discharge controlling will probably affect erosional forces.

\subsection{Current Regulation of the Kokemäenjoki Watershed}

Regulation of the lakes in the Kokemäenjoki watershed in its current form started during 1950-1970, and, in the river section, it started during 1920-1950. The original objective of the regulation was to enhance hydropower production, ease timber rafting and water transport, and enable flood protection. Evening out the water flows on a yearly basis has also been important. Nowadays, the watershed is heavily affected by short-term (daily) regulation, depending on the hydropower production demands.

The most important regulated lakes in the Kokemäenjoki watershed are Lake Pyhäjärvi, Lake Näsijärvi, Lake Kyrösjärvi, Lake Vanajavesi, and Lake Rauta-Kulovesi (Figure 1b, Table 1). Lakes Näsijärvi and Vanajavesi discharge into Lake Pyhäjärvi, and, Lakes Pyhäjärvi and Kyrösjärvi discharge into Lake Rauta-Kulovesi, which is the starting point of the main river. In Lake Pyhäjärvi (Melo power plant), Lake Näsijärvi (Tammerkoski, four power plants), Lake Rauta-Kulovesi (Tyrvää power plant), and Lake Kyrösjärvi (Kyröskoski power plant), the outflow changes daily or weekly. Lake Vanajavesi is regulated by the Herralanvirta dam and Lempäälä canal, but there is no power plant and therefore no short-term regulation. The regulation is legally defined by regulation permits, which include regulation limits for water levels and discharges. Furthermore, regulation is guided by recommendations with the goal of considering different interest groups (flood protection, energy production, environment and water protection, navigation and recreational use) and seasonal variability. Operational regulation is conducted by several operators in cooperation between them and the water authority (Regional Centre for economic development, transport and the environment, later ELY Centres), particularly in exceptional circumstances such as flood [70,71]. 
Table 1. The most important regulated lakes of the Kokemäenjoki watershed, source: Finnish Environment Institute, 2016 [70].

\begin{tabular}{ccccccc}
\hline Sub-Basin & $\begin{array}{c}\text { Annual Water Level } \\
\text { Fluctuation }\end{array}$ & Lake Area & Outlet & Power Plant & $\begin{array}{c}\text { Average Outflow } \\
\left(\mathbf{m}^{3} / \mathbf{s}\right)\end{array}$ & Operator \\
\hline Rauta-Kulovesi & $0.86 \mathrm{~m}$ & $66 \mathrm{~km}^{2}$ & 2. & YES & 187 & $\begin{array}{c}\text { UPM-Kymmene PLC } \\
\text { Kyröskosken Voima JSC } \\
\text { Kyrösjärvi }\end{array}$ \\
$\begin{array}{c}\text { Pyhäjärvi } \\
\text { Näsijärvi }\end{array}$ & $1.19 \mathrm{~m}$ & $96 \mathrm{~km}^{2}$ & 3. & YES & UPM-Kymmene PLC \\
Tampereen \\
Vanajavesi
\end{tabular}

According to the regulation permits, water levels are lowered during winter to ensure the storing capacity for the spring flood. In Lakes Pyhäjärvi, Näsijärvi, and Vanajavesi, the maximum accepted water levels are lower during spring and autumn than in summer in order to maintain good working conditions for the heavy farming machines in the fields next to the lake. During summer, water levels are usually kept close to upper regulation limits. Currently, the regulation limits do not consider the existing snow amount, temperatures, or the timing of the snowmelt, only the date.

Regulation of the lake water levels controls the discharge of the Kokemäenjoki River. As the lake water levels decrease during the winter and early spring, the outflow of the lakes (i.e., the river discharge) increases. For example, in the Harjavalta dam, which is the lowest hydropower plant on the Kokemäenjoki River, wintertime runoff is about one fifth greater than it would naturally be [71]. During spring and summer, the outflow peaks decrease compared to the unregulated situation. During flood discharges $\left(>460 \mathrm{~m}^{3} / \mathrm{s}\right)$, there is no short-term regulation.

\section{Data and Methods}

This study exploited existing data from the reference (R) period (years 1985-2014) and hydrological scenarios and prospective future (F) regulation strategies for a climate change period (years 2050-2079) based on the work by Dubrovin et al. [51,72]. These data were used as input data in the CFD modeling of this study (Figure 2).
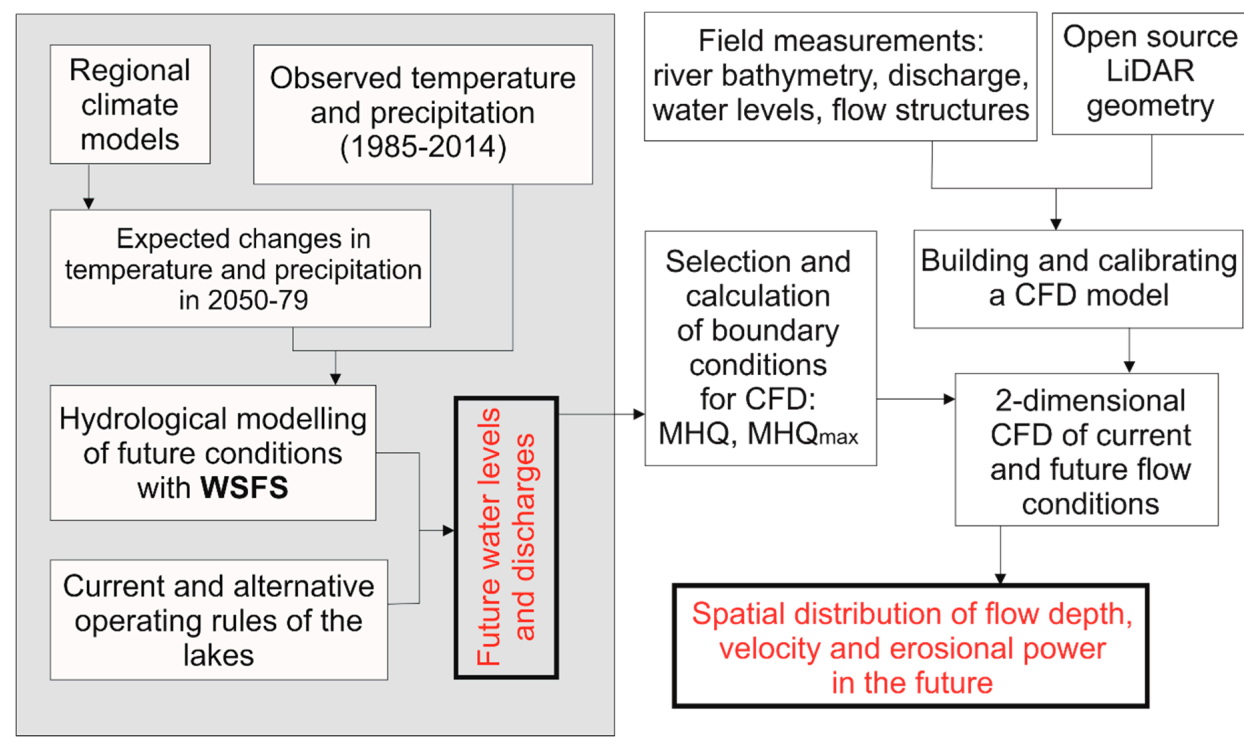

Figure 2. Data and workflow. The hydrological scenarios for the climate change period (2050-2079) and the alternative regulation strategies, produced by the Finnish Environment Institute and ELY Centres, were used as initial data (left) [51,72]. The WSFS stands for Watershed Simulation and Forecasting System. The work related to 2D hydraulic modeling of the flow characteristics (right) was performed in the current study. MHQ stands for the mean high discharge. 


\subsection{Boundary Conditions for the CFD: Future Hydrological Scenarios and Regulation Strategies}

\subsubsection{Climate and Hydrological Scenarios}

The input data regarding the future hydrological scenarios (i.e., the water levels and discharges) applied in the current work are based on a study by the Finnish Environment Institute and the regional ELY Centres on the co-effect of climate change and different regulation alternatives in the Kokemäenjoki watershed [51]. Their study aimed improve the recommendations for regulation of the central lakes of the area. The study is published only in Finnish, and thereby, a short description of the modeling procedure is provided here. They simulated the climate change impacts on the lake water levels and on the discharge of the Kokemäenjoki River using a hydrological model called the Watershed Simulation and Forecasting System (WSFS) [73]. The WSFS is a conceptual hydrological model used for operational flood forecasting and various research purposes. The WSFS simulates the hydrological cycle using standard meteorological data such as precipitation and temperature, as input data. The WSFS model is calibrated against long time series of available water level and discharge observations [73]. The calibration period for the WSFS was 1981-2014 and the Nash-Sutcliffe Efficiency criterion (NSE) for this period for the Harjavalta observation site at Kokemäenjoki was 0.80 . The corresponding figure for the validation period (1971-1980) was 0.83 . This can be considered adequate performance especially since the short-term regulation affecting the observations is modeled with simple regulation rules [59]. The model simulates snow accumulation and melt, soil moisture, ice cover and frazil ice formation, evaporation, groundwater, and runoff, as well as discharges and water levels of main rivers and lakes. To estimate frazil ice formation, the WSFS model uses daily discharges and both air and water surface temperatures. For example, in the lower reach of River Kokemäenjoki, for frazil ice formation, the river discharge higher than $400 \mathrm{~m}^{3} / \mathrm{s}$, air temperature lower than $-4{ }^{\circ} \mathrm{C}$ (from November to February), and water surface temperature lower than $1{ }^{\circ} \mathrm{C}$ with no ice cover are required [74]. During spring and autumn, the air temperature limit is lower, depending on the month. When all these criteria meet, frazil ice starts to affect the simulated river water level in Pori.

In climate change simulations, a historical control period of 30 years (1985-2014) was used as the reference period, and the climate change impacts were predicted for a 30-year period in the future 2050-2079. Monthly changes in temperature and precipitation were calculated for each sub-watershed and used to transfer the climate signal to the WSFS with a "delta change" approach [75,76]. Eight climate scenarios were used (Table 2) from four different regional climate models (RCMs) and four different global climate models (GCMs). Seven of the scenarios were from individual regional climate model-global climate model combinations from the ENSEMBLES project data archive $[77,78]$ and the eighth scenario was an (monthly) average of the seven scenarios (Table 2). The A1B emission scenario was used since the ENSEMBLES data were available with this scenario at the time of the beginning of the hydrological simulations in 2015. Even with one emission scenario the range of temperature and precipitation changes with different GCMs and RCMs is large (Table 2). The average of the seven scenarios was selected for the further analysis as its results correspond well with the mean of the seven scenarios, and it produces more stable results for monthly changes with less impact from natural variability. Because the majority of the scenarios project a similar direction of change, the average scenario provides a representative image of the direction of the potential changes and their impacts on the river environments. However, the uncertainties in climate change projections should be taken into account when making conclusions from the results. 
Table 2. Climate scenarios used and their change in temperature and precipitation from 1985-2014 to 2050-2079 and the simulated average discharge and MHQ in 2050-2079. Dubrovin et al. [51] also applied these values, even though they did not provide the details in their report. The first part of a climate scenario abbreviation describes the regional climate model and the latter part the global climate model, used in the scenario.

\begin{tabular}{|c|c|c|c|c|c|c|}
\hline $\begin{array}{c}\text { Climate Scenario } \\
\text { Abbreviation }\end{array}$ & $\mathrm{RCM}$ & GCM & $\begin{array}{l}\text { Temperature } \\
\text { Change }\left({ }^{\circ} \mathrm{C}\right)\end{array}$ & $\begin{array}{l}\text { Precipitation } \\
\text { Change (\%) }\end{array}$ & $\begin{array}{c}\text { Average } \\
\text { Discharge }\left(\mathrm{m}^{3} / \mathrm{s}\right)\end{array}$ & MHQ $\left(\mathrm{m}^{3} / \mathrm{s}\right)$ \\
\hline Reference period & & & & & 235 & 626 \\
\hline Average scenario & several (see below) & several (see below) & 2.3 & 8.2 & 242 & 678 \\
\hline HIRH-A & HIRHAM 5 & ARPEGE & 2.1 & -1.1 & 204 & 615 \\
\hline RCA-H & RCA4 & HadCM3Q0 & 1.6 & 11.0 & 266 & 689 \\
\hline RCA-E & RCA4 & Echam5 & 2.4 & 10.3 & 256 & 721 \\
\hline RCA-B & RCA4 & $\mathrm{BCM}$ & 1.9 & 8.3 & 248 & 660 \\
\hline Had-H & HadRMQ0 & HadCM3Q0 & 3.5 & 7.8 & 225 & 662 \\
\hline REMO-E & REMO & Echam5 & 2.4 & 7.9 & 242 & 681 \\
\hline HIRH-E & HIRHAM 5 & Echam5 & 2.3 & 13.5 & 271 & 731 \\
\hline
\end{tabular}

For WSFS simulation, the expected average monthly temperature changes were added to the observed temperatures, and precipitation changes in per cent were multiplied by the observed daily precipitations of the reference period [79]. A temperature-dependent component was added to the temperature change to account for the different changes in different parts of the temperature distribution. This means that, for example, cold winter temperatures are increasing more than the warmer temperatures [35]. These modified values were used as input of the WSFS model for each sub-basin and new discharges and water levels for the 30-year climate change period were simulated using the WSFS (Figure 3). Sea level was expected to remain the same as in the corresponding time at the reference period, and no land uplift was considered. The simulated discharges were routed between sub-basins towards downstream taking into account the delays caused by the rivers and regulation. Thus, in the eventual discharge and water level values of the study reach of the lower Kokemäenjoki (Figure 1c), the regulation of each regulated lake (Table 1) is taken into account.

\subsubsection{Future Discharges and Water Levels with Alternative Regulation Strategies}

In WSFS, the lake regulation modeling is based on regulation rules, that is, the discharge of each day depends on prevailing lake water level and day of the year. To model current regulation practice (CURR strategy), Dubrovin et al. [51] adjusted the regulation rules for each lake to follow current regulation limits and practices, so that the simulated water levels and discharges approximately corresponded to the observations.

Based on the simulated data of Dubrovin et al. [51], using CURR strategy both in reference and future period, average winter discharges in the Kokemäenjoki River are projected to increase $20-40 \%$ by $2050-2079$ depending on the climate scenario. Discharge and water level peak values in the Kokemäenjoki will increase. It will also be difficult to reach suitable water levels in the lakes in late spring and early summer because of lower and earlier spring inflow peak in the future, if the lake water levels are lowered in early spring according to the current rules. Thereby, Dubrovin et al. [51] defined alternative regulation strategies for the five central lakes, taking into account the future hydrological conditions. To illustrate climate change adaptation and different objectives, they provided two enhanced regulation strategies with different emphasis: one emphasizing ecological lake water levels (ECO strategy) and the other one supporting recreational usage of the lakes (REC strategy). Both strategies also considered flood risk management.

In the ECO strategy, different ecological groups affected by the lake water level fluctuations are taken into account: littoral zone, fish species, ice-sensitive species, and birds. The ecological impacts were estimated with numerical indicators, which were developed in the Finnish Environment Institute during various regulation development studies [80]. Various measures related to changes and periodicity of the lake water level and ice cover were used to define the most suitable conditions for those ecological groups with different preferences. However, the ecological impacts of regulation 
strategies contain uncertainties due to lake-specific factors and because the co-effect with other impacts of climate change on ecology was beyond the scope. The principal objectives for lake water levels when adjusting regulation rules in ECO strategy were raising the lowest water levels in March and April compared to CURR strategy, and earlier and higher spring high water levels. Additionally, preparation for winter floods is included in ECO strategy by lowering the water levels before winter, to allow better management possibilities in case of flood [51].

In REC strategy, the primary aim is to keep the lake water levels, when possible, on the most favorable zone for recreational use during the summer (early May to late October). The water level zones are based on the empirical knowledge of the public authorities, users' opinions gathered by inquiries, and the water levels determined in previous regulation development studies [81]. REC strategy includes raising the lowest spring water levels compared to CURR strategy in order to reach the target water level zones in May, as well as lowering water levels before winter when possible.

According to results by Dubrovin et al. [51], lower water levels before winter and milder winter draw-down of the lakes in both strategies ECO and REC lead to lower river discharge in winter in period 2050-2079, compared to CURR strategy (Figure 4). High discharges mainly increase in late spring in the ECO and REC strategies compared to the CURR strategy due to lower available storing capacity of the lakes. Spring water levels are mainly even slightly higher in ECO than in REC strategy. In REC strategy, the lake levels are kept more stable through the summer, and discharge is often slightly lower in summer than in ECO. The total available storage capacity in lakes before winter is the largest in ECO strategy and the smallest in CURR strategy. It should be noted that the adaptive regulation strategies used in this study are just two examples of how the regulation rules could be modified to favor some ecological and recreational objectives, and diminish flood risk in the future.

Using 2D computational fluid dynamics, we modeled the flow conditions during both the reference period ( $R, 1985-2014)$ and the future climate change period (F, 2050-2079); in total, we modeled seven cases (Table 3). To illustrate the expected changes in the seasonality and magnitude of typical high flow events in the future, we simulated the mean high discharge events (MHQ). The MHQ was calculated as the average of the highest annual discharges of the investigated period, for the reference period ( $R$ CURR MHQ) and for the future with each regulation alternative (F CURR MHQ, F ECO MHQ, and F REC MHQ). The water level for the MHQ simulations was defined by averaging the prevailing water levels of each high discharge event used to calculate the MHQ. The high flow events were then compared with a normal flow situation (R CURR n) which prevailed, for example, on 17 August 2007.

Table 3. The CFD models and their boundary conditions of Part 2 for the reference period (R) and for the future (F). CURR, current regulation rules; ECO, ecologically sustainable regulation rules; REC, regulation rules supporting recreational usage. $\mathrm{n}$ refers to normal flow, and MHQ is the mean high discharge with typical water level (normal) and maximum water level (max). $\mathrm{Q}$ is the river discharge $\left(\mathrm{m}^{3} / \mathrm{s}\right)$ at the upstream boundary, and WL down is the water level in meters at the downstream boundary.

\begin{tabular}{ccc}
\hline Model & Q $\left.\mathbf{~ ( m ~}^{\mathbf{3}} \mathbf{s}\right)$ & WL $\mathbf{~ ( m ) ~}$ \\
\hline R CURR n (i.e., Low discharge) & 141 & 0.046 \\
R_CURR_MHQ normal & 626 & 1.09 \\
R_CURR_MHQ max & 626 & 1.36 \\
F_CURR_MHQ normal & 676 & 1.308 \\
F_CURR_MHQ max & 676 & 1.735 \\
F_ECO_MHQ & 649 & 1.25 \\
F_REC_MHQ & 670 & 1.28 \\
\hline
\end{tabular}




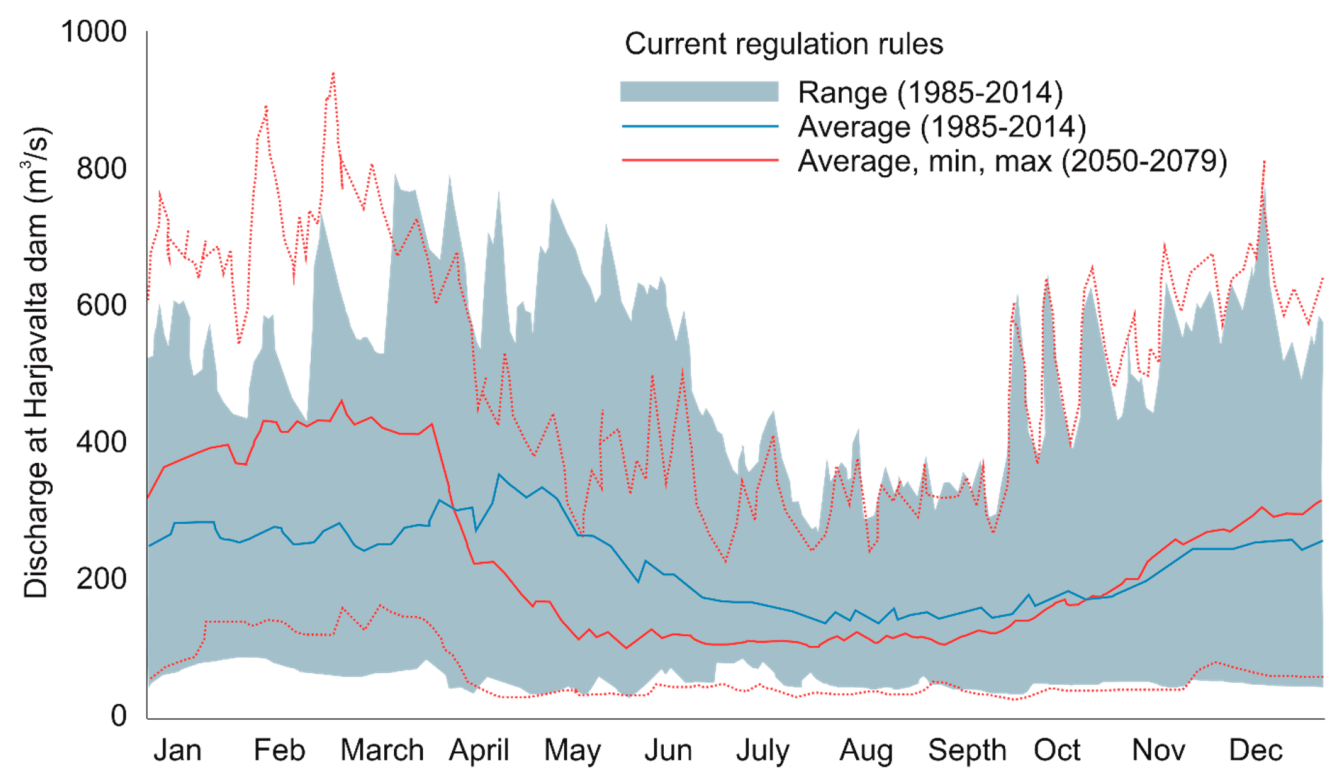

Figure 3. The effect of climate change on the discharge at the Harjavalta dam, shown by comparing the range and average discharge of the control period (1985-2014) with the expected future (2050-2079, average climate change scenario) discharge, using the current regulation rules (CURR). The upper and lower red dotted lines represent the maximum and minimum discharge in the climate change period, respectively. Data were modeled in the study by Dubrovin et al. [51].

In the study area, the sea level variation may significantly contribute to the flood inundation and flow characteristics controlling the water levels with a backwater effect [59]. Thus, the same magnitude of discharge may have various effects depending on the frazil ice and the amount of backwater effect. To illustrate the effect of sea level fluctuation, we also modeled the MHQ discharge using the highest water level, which had prevailed during the MHQ discharge $\left( \pm 5 \mathrm{~m}^{3} / \mathrm{s}\right)$ of the reference period (R CURR $\left.\mathrm{MHQ}^{\max }\right)$. Similarly, the high water level was defined based on the results of the hydrological model for the future (F CURR MHQ ${ }^{\text {max }}$ ). However, the frazil ice did not have effect on the flow event used to calculate the MHQ values, as conditions prone for frazil ice development did not occur. Only backwater effect contributed to the water level, in addition to the model parameters.

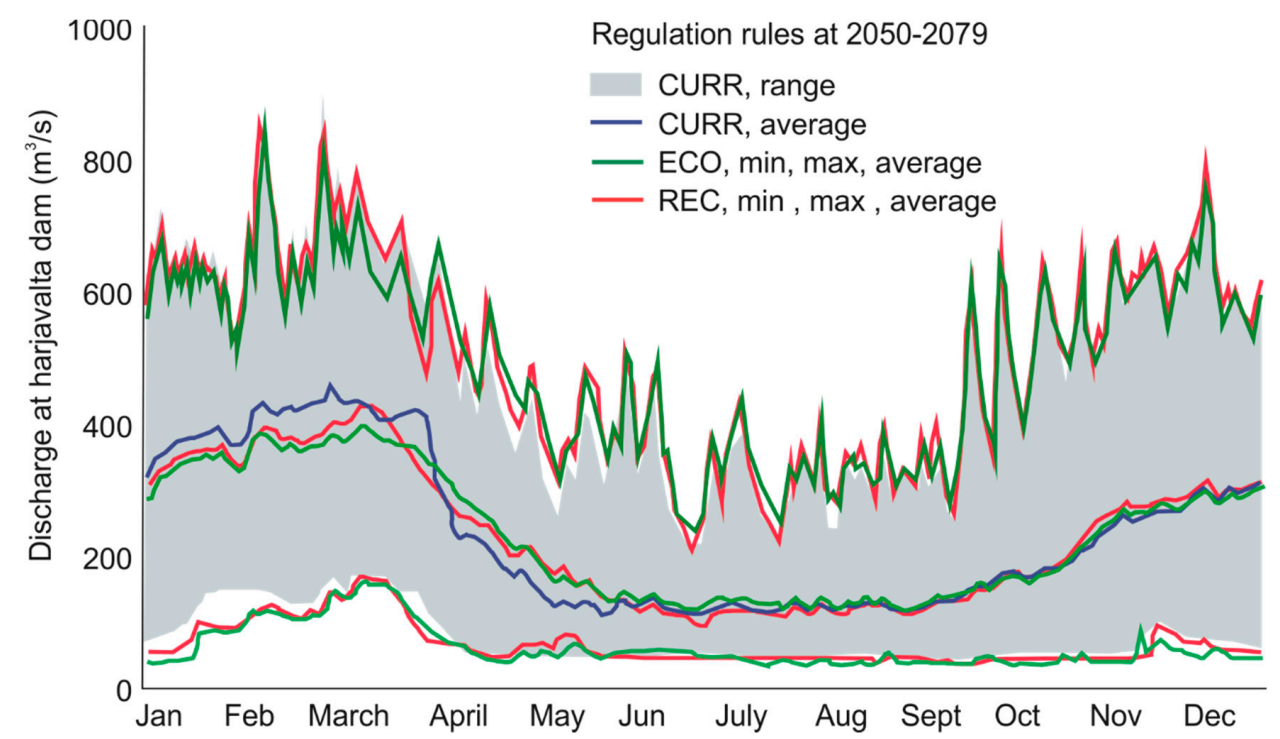

Figure 4. The expected future discharge of the Harjavalta dam with three different regulation strategies, CURR, ECO, and REC, based on the average climate change scenario used in this study. Data were modeled in the study by Dubrovin et al. [51]. 


\subsection{Computational Fluid Dynamics}

To illustrate and analyze the effects of the climate change and regulation on the flow characteristics during a typical high flow event (MHQ), seven different cases were simulated using a 2D hydraulic model (Delft3D FM) (Table 3). The hydraulic model covered a reach of $12 \mathrm{~km}$ from the city of Pori towards the sea, on the lower reach of the Kokemäenjoki River (Figure 1c). In the modeled area, the main channel is $\sim 150 \mathrm{~m}$ wide and up to $5 \mathrm{~m}$ deep, dividing into several $\sim 80$-m-wide distributaries.

\subsubsection{Field Data}

To build a hydraulic model, the channel geometry was built based on data from various sources. Airborne laser scanning data with 10-m point spacing from 2008, describing the geometry of the dry areas, were derived from an open data service, provided by the National Land Survey of Finland. The wet channel geometry was derived by combining standard echo sounding measurements (year 2003), ADCP (Acoustic Doppler Current Profiler)-based multi-beam echo sounding measurements (year 2017), and swathe sonar measurements (year 2016). The standard echo sounding measurements were performed by the Finnish Environment Institute (SYKE) with an MD300 echo sounder system accurate to $\pm 5 \mathrm{~cm}$, and the positions were measured with a dGPS (differential global positioning system) over the whole study area in 2003. The authors of this study fulfilled supplementary bathymetric measurements in August 2017 using a SonTek HydroSurveyor on the reach downstream from the city of Pori. The position of the sonar measurements was determined by an integrated dGNSS (differential global navigation satellite system). These measurements also showed that the channel geometry had not changed dramatically in the estuary since the intensive measurements were taken by Finnish Environment Institutein 2003. The bathymetric data were completed with a commercially produced swathe sonar measurement (year 2016) from the area around the city center. All three datasets were combined, and the resultant point cloud was interpolated to a 10-m resolution grid covering the whole wet area using the Kriging method and converted to point format. This resulted in a point cloud with 10-m point spacing over the study area. This was used as the input data in hydraulic modeling.

The data by Lotsari et al. [49] on sediment characteristics were exploited: they collected in total 107 bed sediment samples between the Harjavalta dam and estuary using a grab sampler. Most of the sediment samples ( $\mathrm{n}=98,90.7 \%$ ) mainly comprised very fine sand, cohesive silt, and clay size particles. The average D50 of the samples was $0.11 \mathrm{~mm}$, varying between 0.002 and $0.45 \mathrm{~mm}$.

Additional data for calibration of the hydraulic model (i.e., water level and flow profile data) were collected in August 2017 by the authors. The water surface slope on the study area was measured with a VRS-GNSS (virtual reference station GNSS). The flow velocity profile was measured at the city center using the SonTek RiverSurveyor M9 [82].

\subsubsection{CFD Implementation and Calibration}

To model the fluid dynamics, a Delft 3D FM software in two dimensions was used. The model uses an alternating direction implicit (ADI) method (a finite difference method) to solve the momentum and continuity equations (see Leendertse [83] and a cyclic method for the spatial discretization of the horizontal advection terms (see Stelling and Leendertse [84]). The equations were described in detail, for example, by Kasvi et al. [85,86]. Sub-grid scale mixing coefficient of the flow (horizontal eddy viscosity) was used to describe turbulence. The 2D Reynolds-averaged momentum and continuity equations were implemented on a curvilinear, unstructured grid. The resolution of the grid varied between 5 and $40 \mathrm{~m}$ so that the resolution was coarser on the edges of the modeled area. The channel itself had a resolution higher than $15 \mathrm{~m}$. The topographical points of 10-m spacing were imported to Delft3D FM and interpolated over the grid using triangulation. The resultant computational grid was then compared with the original point data (Table 4). The average error caused by the interpolation of the point data into the computational grid was $0.10 \mathrm{~m}$, and the average absolute error was $0.29 \mathrm{~m}$. 
The floodplain values were evaluated separately due to very low topographical variation. The average error on the floodplain was $0.04 \mathrm{~m}$, and the absolute error was $0.09 \mathrm{~m}$.

Table 4. The errors of the elevation on the computational grid compared to the original topographical point data with $10 \mathrm{~m}$ point spacing.

\begin{tabular}{cc}
\hline Entire area & error $(\mathbf{m})$ \\
\hline Average error & 0.1 \\
Average abs error & 0.29 \\
Floodplain & error $(\mathbf{m})$ \\
\hline Average error & 0.04 \\
Average abs error & 0.09 \\
\hline
\end{tabular}

The hydrodynamic model was calibrated using field observations from a field campaign in August 2017, when the water level, discharge, and flow profiles were measured. At that time, the discharge at the upstream boundary was $189 \mathrm{~m}^{3} \mathrm{~s}^{-1}$, and the water level was $0.25 \mathrm{~m}$ at the downstream boundary and $0.35 \mathrm{~m}$ at the calibration data point (see Figure $1 \mathrm{c}$ for the location of the calibration point). By adjusting the Manning's roughness coefficient and horizontal eddy viscosity, modeled water level and flow velocities corresponding to the field measurements were obtained. The calibration was considered successful when the modeled water level at the calibration data point was within $5 \mathrm{~cm}$ from the measured value $(0.35 \mathrm{~m})$. The final calibration run, with a Manning's roughness coefficient of 0.017 and horizontal eddy viscosity of 0.1 , resulted to $3 \mathrm{~cm}$ difference in the calibration point water level. After that, the modeled flow velocities were compared with the measured depth-averaged flow velocities. The modeled velocities were diagnosed to be within $5 \%$ of the measured ones.

Next, the model was validated using four different high flow events from April 2010 to demonstrate the models performance (Table 5). The differences in the modeled and measured water levels at the calibration point were less than $10 \mathrm{~cm}$ in each case, the largest difference $(7 \mathrm{~cm})$ being the case with highest discharge, on 12 April. On that day, however, the sea level, and thereby also the water levels at the downstream boundary and calibration point have been relatively low (note the same water levels on 11 April with lower discharge). Thereby, we assume that the weakening model performance in that case is not directly related to the high discharge but rather to the complex water level fluctuations of the area. The mean error of the four validation runs at the calibration data point was $0.045 \mathrm{~m}$.

Table 5. The results of the validations runs of the hydrodynamic model. WL stands for water level and the unit is meters. "Error" means the modeling error at the calibration point.

\begin{tabular}{cccccc}
\hline Date & Q (m) $\mathbf{3}$ s) & WL Down & $\begin{array}{c}\text { WL Calibration Point } \\
\text { (Measured) }\end{array}$ & $\begin{array}{c}\text { WL Calibration Point } \\
\text { (Modeled) }\end{array}$ & Error \\
\hline 11 April 2010 & 541 & 0.53 & 0.93 & 0.88 & 0.05 \\
12 April 2010 & 573 & 0.53 & 1.02 & 0.95 & 0.07 \\
18 April 2010 & 448 & 0.43 & 0.77 & 0.73 & 0.04 \\
21 April 2010 & 393 & 0.38 & 0.64 & 0.62 & 0.02 \\
\hline
\end{tabular}

After that, each case (Table 3) was modeled as a steady state model of 24 hours using a time step of $10 \mathrm{~min}$. The spatial and temporal variations of flow depth were extracted from the simulation results. Based on the results, the distribution of bed shear stress $\left(\mathrm{BSS}, \mathrm{N} \mathrm{m}^{-2}\right.$ ) was calculated for each case as follows [87]:

$$
\tau_{0}=\rho g d s,
$$

where $g$ is the gravitational acceleration $\left(9.81 \mathrm{~m} \mathrm{~s}^{-2}\right), \rho$ is the density of water $\left(1000 \mathrm{~kg} \mathrm{~m}^{-3}\right), d$ is flow depth, and $s$ is the slope of water. The last two parameters were derived from the hydraulic model. 
After that, the critical bed shear stress of the initiation of sediment motion $\tau_{c r}$ was calculated for the average $D_{50}$ grain size in the area as follows [88]:

$$
\tau_{c r}=K g\left(\rho_{s}-\rho\right) D_{50}
$$

where $K$ is a constant (0.045), $g$ is the gravitational acceleration, $\rho_{s}$ is the density of sediment (i.e., of quartz being $2650 \mathrm{~kg} \mathrm{~m}^{-3}$ ), and $D_{50}$ is the average median grain size of the area in meters. The $D_{50}$ of the area, based on 43 sediment samples, was $0.11 \mathrm{~mm}$ and the critical bed shear stress was $0.081169 \mathrm{~N} \mathrm{~m}^{-2}$.

\section{Results}

The flow depth and erosional power (Bed shear stress) of the typical high flow events (during the control period and during 2050-2079 with different regulation rules), were compared with the low flow case and with each other. During a normal flow event, the land areas between the distributaries remain dry and the bed shear stress varies between 0.2 and $1 \mathrm{~N} / \mathrm{m}^{2}$ (Figure 5 ). In the main channels (i.e., Raumanjuopa and Luotsinmäenjuopa), especially, the bed shear stress remains higher than the critical bed shear stress $\left(0.08 \mathrm{~N} / \mathrm{m}^{2}\right)$ to move the average sediment particles in the area (Figure 5).

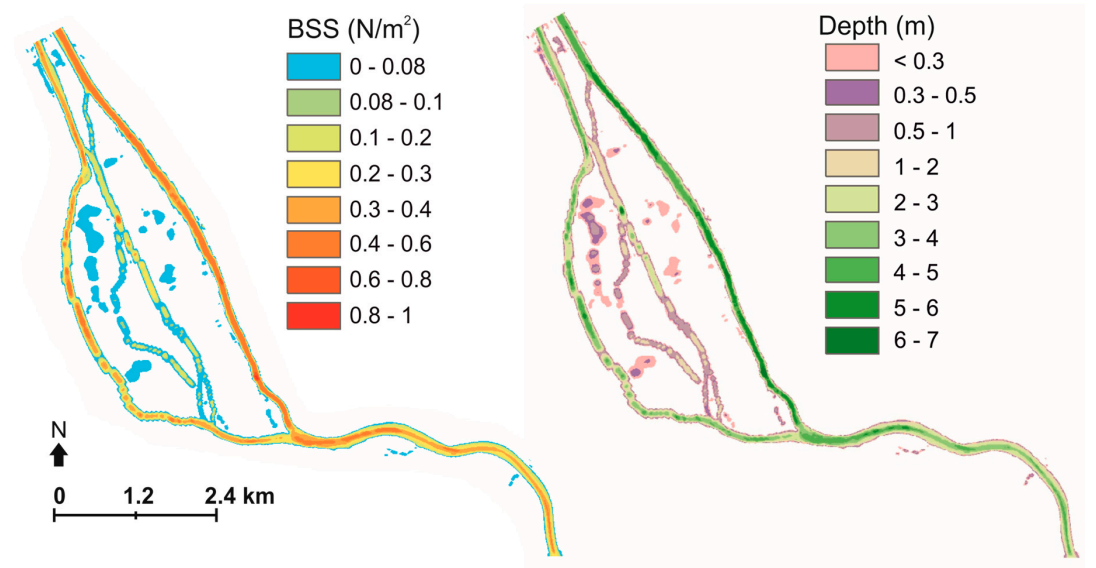

Figure 5. The distribution of BSS (left) and depth (right) during a low discharge case of the control period. The areas with bed shear stress lower than $0.08 \mathrm{~N} / \mathrm{m}^{2}$, which is the critical value for the initiation of movement of the $D_{50}$ gains, is marked with blue color.

Based on our results, the inundated areas will expand during a typical high flow events (MHQ) regardless of the adjusted regulation rules (Figure 6). Of all the modeled cases, the largest inundated area $\left(8.96 \mathrm{~km}^{2}\right)$ and flow depth (mean depth of $1.51 \mathrm{~m}$ ) are expected in the climate change period with the current regulation rules and when the highest expected water level, occurring simultaneously with the MHQ, is taken into account (F CURR MHQ max) (Table 3 and Figure 6d). If the current regulation rules are used in the future, the mean high discharge will increase $8 \%$ from the control period as a consequence of climate change (Table 3). This will cause only a minor increase in the mean flow depth (from $1.14 \mathrm{~m}$ to $1.25 \mathrm{~m}$ ), but the inundated area will expand by $15 \%\left(0.9 \mathrm{~km}^{2}\right)$ with the average water level during the MHQ flow, due to the topographically flat terrain (Table 6 and Figure $6 a, c)$. If the highest plausible water level during the MHQ is considered (MHQ max), the inundated area will increase $30 \%$ in the future from the control period in the modeled area.

Based on our results, however, the frequent high flow event may be restrained by enhanced regulation rules in the future (Table 6 and Figure 6). The annual mean high discharge may be diminished by up to $4 \%$ with the proposed regulation changes, which would reduce the inundated area by $2-5 \%$, which means up to $320,000 \mathrm{~m}^{2}$ (Table 6). The inundated area during an MHQ discharge in the climate change period will be $10 \%$ or $13 \%$ larger than in the control period if the ECO or REC strategy is used, respectively (compared to 15\% with the CURR strategy) (Table 6). 
Table 6. The inundated area, mean flow depth, and water level at the Pori city center of each modeled case, based on the 2D hydrodynamic model. The discharges and downstream water levels used in the models are shown in Table 3. The location of the Pori city center is shown in Figure 1c.

\begin{tabular}{cccc}
\hline Model & Inundated Area $\left(\mathbf{k m}^{\mathbf{2}}\right)$ & Mean Depth $(\mathbf{m})$ & WL at Pori City Center $(\mathbf{m})$ \\
\hline R_CURR_N & 3.71 & 0.74 & 0.13 \\
R_CURR_MHQ & 5.8 & 1.14 & 1.42 \\
R_CURR_MHQ max & 6.89 & 1.27 & 1.60 \\
F_CURR_MHQ & 6.7 & 1.25 & 1.59 \\
F_CURR_MHQ max & 8.96 & 1.51 & 1.90 \\
F_ECO_MHQ & 6.38 & 1.22 & 1.53 \\
F_REC_MHQ & 6.53 & 1.24 & 1.57 \\
\hline
\end{tabular}
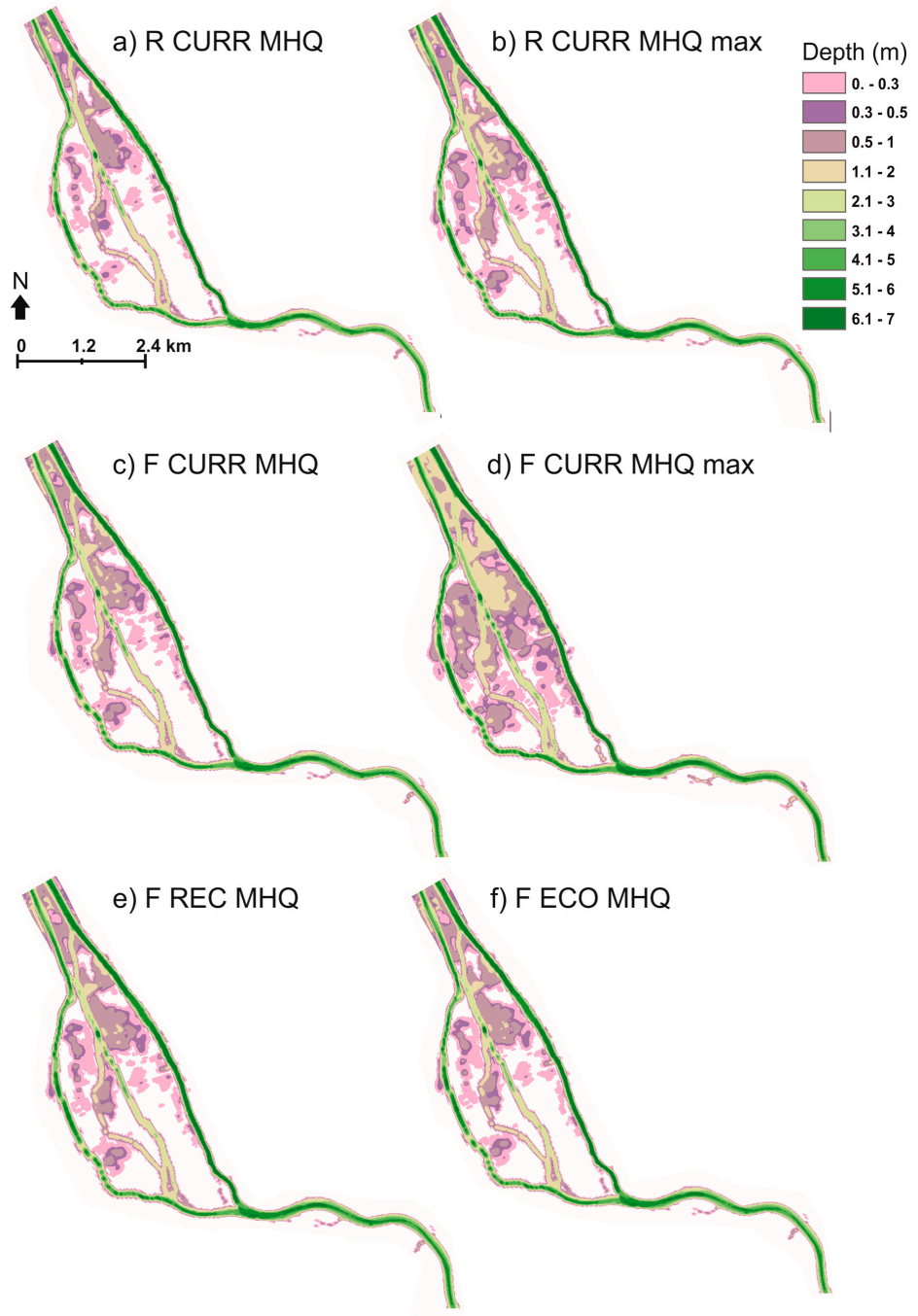

Figure 6. Flow depth during high flow events in the control period $(\mathbf{a}, \mathbf{b})$ and in the climate change period (c-f) with: (a) MHQ discharge, current regulation rules, and an average water level (R CURR $\mathrm{MHQ}$ ); (b) MHQ discharge, current regulation rules, and the maximum water level (R CURR MHQ max); (c) MHQ discharge, current regulation rules, and an average water level (F CURR MHQ); (d) MHQ discharge, current regulation rules, and the maximum water level (F CURR MHQ max); (e) MHQ discharge, ECO regulation rules, and an average water level (F ECO MHQ); and (f) MHQ discharge, REC regulation rules, and an average water level (F REC MHQ).

Despite the expected increase in the discharges and inundated areas, erosional power in the study area will decrease during the typical high flow events in the near future (Figure 7). Because the frazil ice affects the applied boundary values of the CFD simulations, the cause of this decrease relates only 
to the differences in water level slope (i.e., slightly higher water level conditions). During the MHQ discharge of the control period, the erosional power of the flow in the main channel is multiplied compared to the normal flow situation: BSS is mostly between 2 and $2.5 \mathrm{~N} / \mathrm{m}^{2}$ in the main channel (compared to $0.2-1 \mathrm{~N} / \mathrm{m}^{2}$ during the normal flow) (Figure 7a,b). The critical BSS value of $0.08 \mathrm{~N} / \mathrm{m}^{2}$ is not exceeded at the boundaries of the flat floodplain areas, outside of the channels, over which the flood water spreads (Figure 7a). The distribution of the erosional power during an MHQ flow in the future seems rather similar to that of the reference period (Figure 7c): the BSS of $1.5-2.5 \mathrm{~N} / \mathrm{m}^{2}$ dominates the main channels. This means an increase of $1-1.5 \mathrm{~N} / \mathrm{m}^{2}$ in the BSS in the main channel compared to the normal flow situation (Figure 7d). On average, the MHQ flow causes an increase of $0.375 \mathrm{~N} / \mathrm{m}^{2}$ and $0.357 \mathrm{~N} / \mathrm{m}^{2}$ compared to the normal flow in the reference period and in the future, respectively. The BSS during atypical high flow event will thus decrease slightly in the future (Figure 7e) with larger differences if the maximum probable water level (MHQ max) is taken into account (Figure 7f).
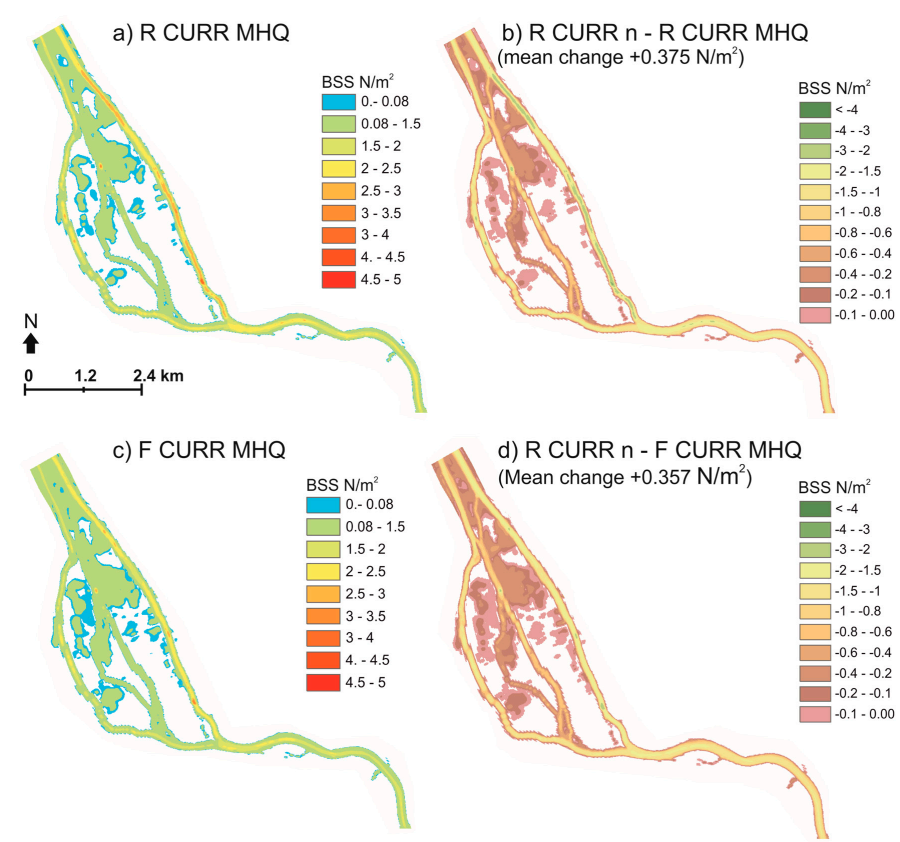

d) R CURR n - F CURR MHQ
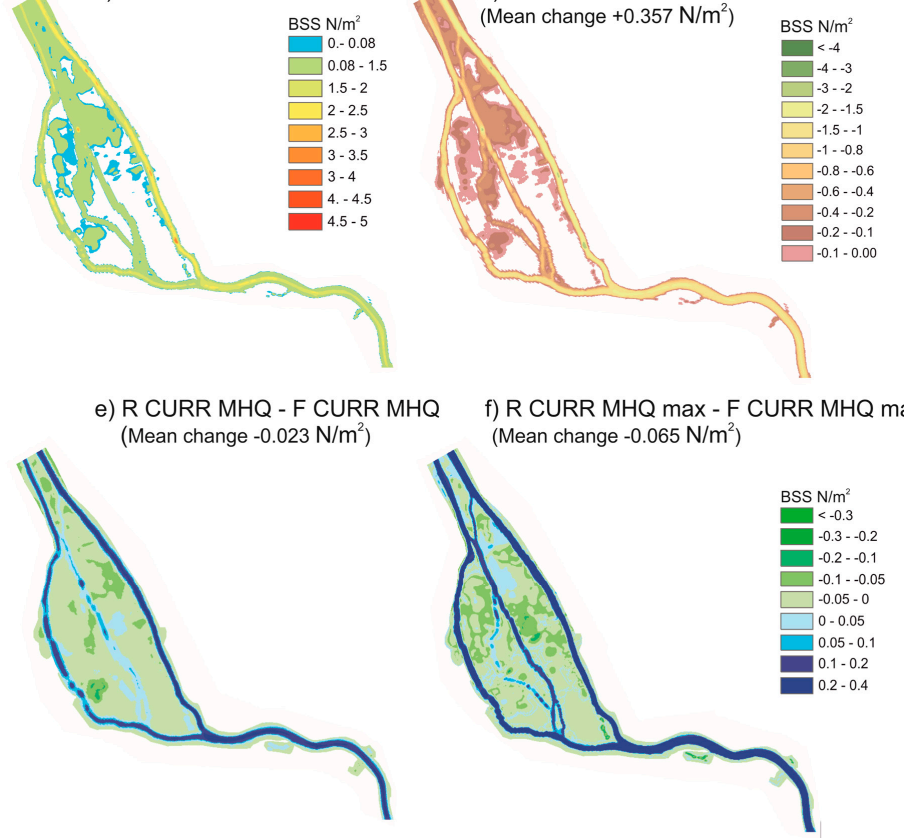

Figure 7. Bed shear stress during flood events: (a) the distribution of BSS at the control period (R CURR MHQ); (b) the difference in BSS between the normal and flood flow in the control period (R CURR $\mathrm{n}-\mathrm{R}$ CURR MHQ); (c) The distribution of BSS in the climate change period with current regulation rules (F CURR MHQ); (d) the difference in BSS between the normal and flood flow in the climate change period (RCURR CURR n - F CURR MHQ); and the difference in BSS between the MHQ floods of the reference and climate change periods: (e) with normal water level (R CURR MHQ - F CURR MHQ); and (f) with maximum water level (R CURR MHQ max - F CURR MHQ max (BSS). The mean differences are marked in the figures. 
On average, the bed shear stress during a typical high flow events will diminish $0.023 \mathrm{~N} / \mathrm{m}^{2}$ and $0.065 \mathrm{~N} / \mathrm{m}^{2}$ for the MHQ and MHQ max, respectively in the climate change period compared to the reference period. In the main channel, a decrease up to $0.4 \mathrm{~N} / \mathrm{m}^{2}$ is expected in both cases (Figure $7 \mathrm{e}, \mathrm{f}$ ). The proposed regulation rules (ECO and REC) do not have much influence on the erosional power of the flow during an average flood (Figure 8). In the future hydro-climatological conditions, compared to the CURR strategy, the ECO strategy will slightly decrease the erosional power during an average flood event (mean difference of $-0.0017 \mathrm{~N} / \mathrm{m}^{2}$, Figure 8a), while the REC strategy will increase the BSS (mean difference of $0.019 \mathrm{~N} / \mathrm{m}^{2}$, Figure $8 \mathrm{~b}$ ). In general, the differences between the CURR strategy and the enhanced regulation strategies in the main channel are, in both cases, less than $0.06 \mathrm{~N} / \mathrm{m}^{2}$.
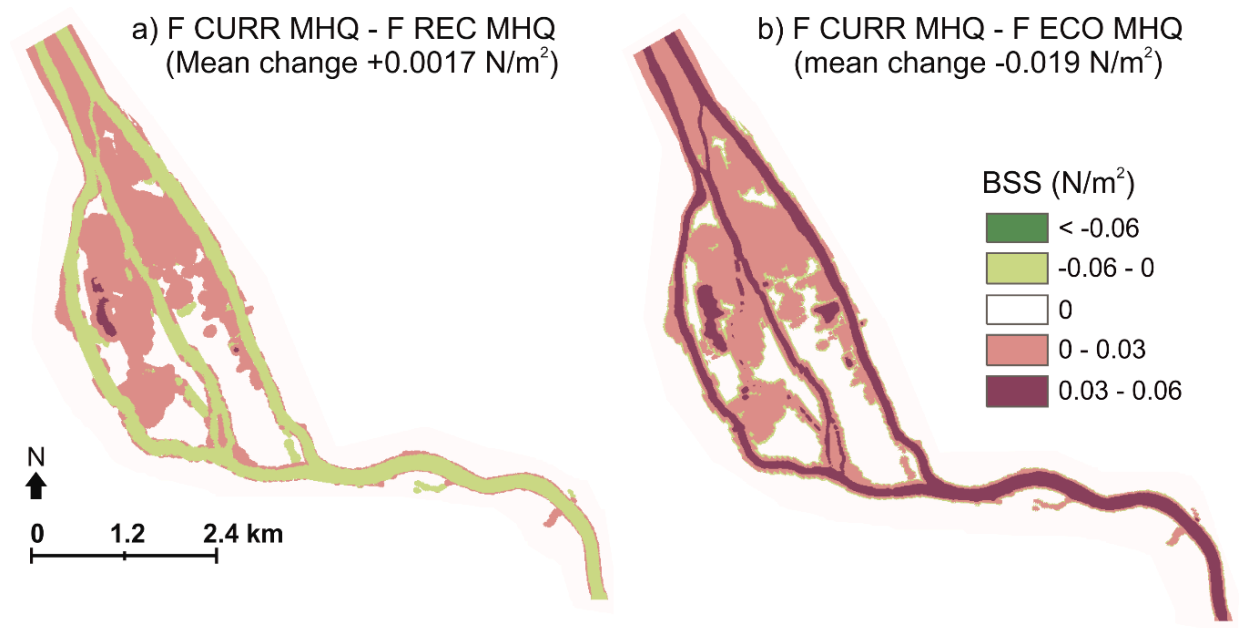

Figure 8. The effect of the enhanced regulation rules to the erosional power. The difference in BSS between: (a) the CURR and REC regulation rules (F CURR MHQ - F REC MHQ); and (b) the CURR and ECO regulation rules (F CURR MHQ - F ECO MHQ) during a flood in the future.

\section{Discussion}

\subsection{The Effect of Climate Change and Flow Regulation on the Flow Characteristics}

In this study, we investigated how the predicted hydro-climatological changes will affect the distribution of fluvial forces and inundated area during typical high-flow situation (MHQ, mean high discharge), and how modifying the regulation standards could alter the climate change impacts in a low-relief river of the Southern Boreal climate area, Southwestern Finland. We focused on typical high flow events, because they repeat regularly and thus may have a great influence on the river morphology at long run [48,50]. In the expected future (2050-2079) hydro-climatological conditions, warming is projected to be substantially above the global average in the South Boreal environment [60]. The warming will and has affected more discernibly wintertime hydro-climatology, especially the earlier flood peaks. In regulated rivers, the climate change impacts may be reduced with suitable changes in the regulation rules. We used hydrologically modeled future flow scenarios and alternative regulation standards developed by the Finnish Environment Institute and ELY Centers [51]. According to their work, the average discharge in the Kokemäenjoki River will increase from $235 \mathrm{~m}^{3} / \mathrm{s}$ at the control period to $242 \mathrm{~m}^{3} / \mathrm{s}$ in the climate change period. However, the most common (largest number of days/per year) river discharge of the control period is $100-150 \mathrm{~m}^{3} / \mathrm{s}$ while in the climate change period it will be $50-100 \mathrm{~m}^{3} / \mathrm{s}$ (Table 3), and the number of days with very low discharge (less than $100 \mathrm{~m}^{3} / \mathrm{s}$ ) will increase (Figure 9). On the other hand, days with very high discharge will increase as well. 


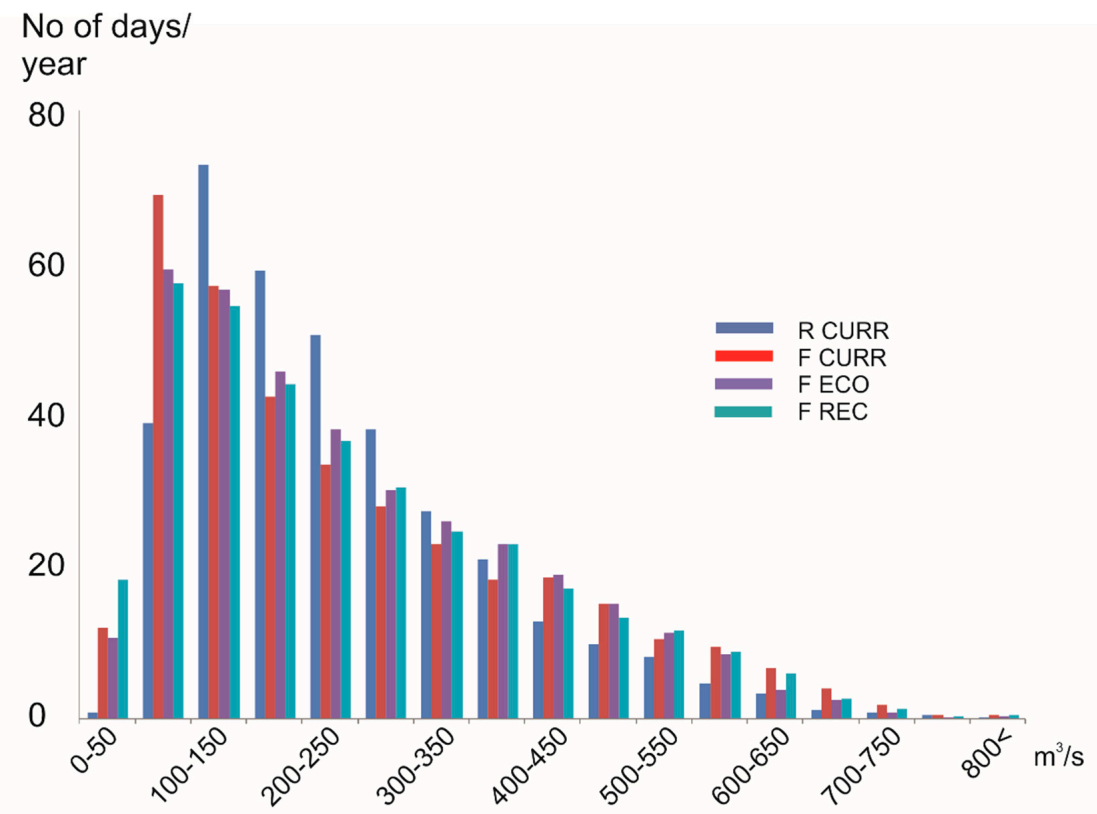

Figure 9. The distribution of daily discharges (in number of days/year) at the city of Pori. Data were modeled in the study by Dubrovin et al. [51].

In the Southern Boreal area, the timing of the snowmelt peaks will be earlier than before, causing wintertime discharges in the rivers, including the peak values and the total runoff and inflows to the lakes, to increase [57]. This will affect the regular high flow events in the near future. Based on this study, it seems evident that the climate change-induced increased runoff will expand the inundated areas during typical (MHQ) high flow events and the adaptive regulation rules are not able to eliminate this, even though they could attenuate the impact. The annual mean high discharge may be diminished by up to $4 \%$ with the adaptive regulation rules, which will reduce the inundated area by $2-5 \%$, which means up to $320,000 \mathrm{~m}^{2}$ in our modeling area. The inundated area during an MHQ discharge in the climate change period will be $10 \%$ or $13 \%$ larger than in the control period if the ECO or REC strategy is used, respectively (compared to 15\% with the CURR strategy). Thus, in addition to the ecological aspects, the ECO strategy is also more adaptive to climate change in terms of flooding. In the Southern Boreal climate areas, especially on the flat terrains, the increase in winter temperature zero-crossings, in addition to high discharges and their daily variation due to hydropower production, means more possibilities for frazil ice flood situations and the flood risk will be an increasing concern [74]. Frazil ice formation in the river can be prevented by lowering the runoff and reducing discharge variation during the freezing period to help ice cover formation $[5,15,74]$. Thus, the possibility to lower the winter discharges by regulation is essential for that as well, and will be an important adaptive practice in the future in the Southern Boreal climate area. Based on our results, using the ECO strategy would cause smallest MHQ discharges and inundation areas of all the strategies.

Based on our 2D modeling, even though the discharges and inundated areas will increase in the near future, the erosion potential will decrease, with larger differences if the maximum probable water level (MHQ max) is taken into account. The most important factor for reducing the shear forces is the reduced water surface slope. This can be attributed to the change of timing in floods from spring to autumn and winter, when the sea levels during flood peaks is on average higher, which reduces the water surface slope with the backwater effect.

Kämäri et al. [47] stated that the wintertime riverine sediment loads in the Kokemäenjoki River are expected to double because of increased discharges by 2070-2099. They appraised adaptive actions, such as discharge controlling, could significantly affect the erosional forces. Our results indicate that 
adaptive regulation (ECO) could reduce the erosional power even more than is expected with the current rules, but its influence is minor and is mainly caused by the reduced discharge. However, as we were studying regular high flow events, the influence of the adaptive regulation may be significant in long term, even though the differences in erosional power were small. Further research is needed on the longer-term effects of different regulation rules and their effects on various flow events.

Lotsari et al. [59]) stated that the erosion potential will overall increase in the Kokemäenjoki River (they simulated longer reach, $\sim 43 \mathrm{~km}$ ), they noticed that the lower river reach, which is mostly affected by the sea, will experience decreasing erosional power in the future, if the maximum relative increase in sea water level will actualize. Their results indicate that the high future sea levels would counteract the impacts of increasing discharges on the erosion potential of the river channel. However, many coastal areas of Finland still experience a relative fall in sea level due to the isostatic land uplift [25] and it is most probable that, by the year 2079, the isostatic land uplift will still exceed the climate change-induced sea level rise in our study area [63]. No climate change impacts on the sea level was considered in the WSFS model in this study, but based on the results of this study and the studies by Lotsari et al. [59] and Pellikka et al. [63], the sea level change will definitely be an important climate change impact on the area affecting flooding in particular. If the sea level rises according to the highest expected scenario (RCP8.5, rise of $0.63 \mathrm{~m}$ by years 2081-2100) [63], it would increase flooding in the lower Kokemäenjoki River already during the climate change period of this study. Our study indicates that timing of flooding may possibly counteract with the rising sea level in increasing flooding on the area. In addition, the short-term sea level variations and expected changes in sea level extremes, such as weather-induced events, should be considered in addition to the long-term mean sea level changes [63].

It has also been stated that the hydropower generation could play an important role in the climate change adaptation of water resource availability, but attention is needed to mitigate the environmental and social impacts in the changing climate [16]. Based on our study, the demands of environment, society, and hydropower generation are not necessarily contradictory in terms of climate change adaptation. Northern Europe belongs to the area of increasing runoff and hydropower generation: an overall increase in river flow and earlier spring peak flows are expected [22,53]. The hydropower production is expected to benefit from the increased runoff in Kokemäenjoki River as well. Dubrovin et al. [51] also estimated the change in hydropower potential $(\mathrm{kWh})$ of 10 hydropower plants in the area with the average climate scenario (Table 2), considering the different regulation rules. They calculated energy $(\mathrm{kWh})$ as a product of hydraulic head, turbine flow, efficiency coefficient, acceleration of gravidity, water density, and number of hours. Based on their study, compared to the control period with the CURR strategy, hydropower production will increase $0.1-1.9 \%$ by $2050-2079$ depending on the regulation strategy (Figure 10). With lower snowmelt flood discharges, the CURR strategy is the most productive during the control period, whereas in 2050-2079, the similar decrease of lake water levels in late winter and early spring will force more water to spill due to early spring floods. On the other hand, the ECO strategy allows for higher water levels in spring, which, along with preparation for winter floods (with lower water levels), will notably reduce the spill over in 2050-2079 compared to other strategies [51]. Thus, in addition to reduced flood risk, the ECO regulation strategy would enable $0.8 \%$ and $1.8 \%$ higher energy production in the future compared to the REC and CURR strategies, respectively. In terms of hydropower production, the REC strategy is between the two other strategies in the climate change period. It should be noted that the economic value of hydropower depends not only on the amount of energy but also on the energy need, that is, the timing of the production. In general, the energy price is higher during the most energy-intensive cold season. The short-term (weekly or daily) regulation, which is conducted at the hydropower plants in the study area to correspond to the daily fluctuations in the energy demands, was not included in the model of Dubrovin et al. [51]. Sources of uncertainty include assumed constants (head and efficiency coefficient) in addition to uncertainties in climate scenario, hydrological model and regulation model. 


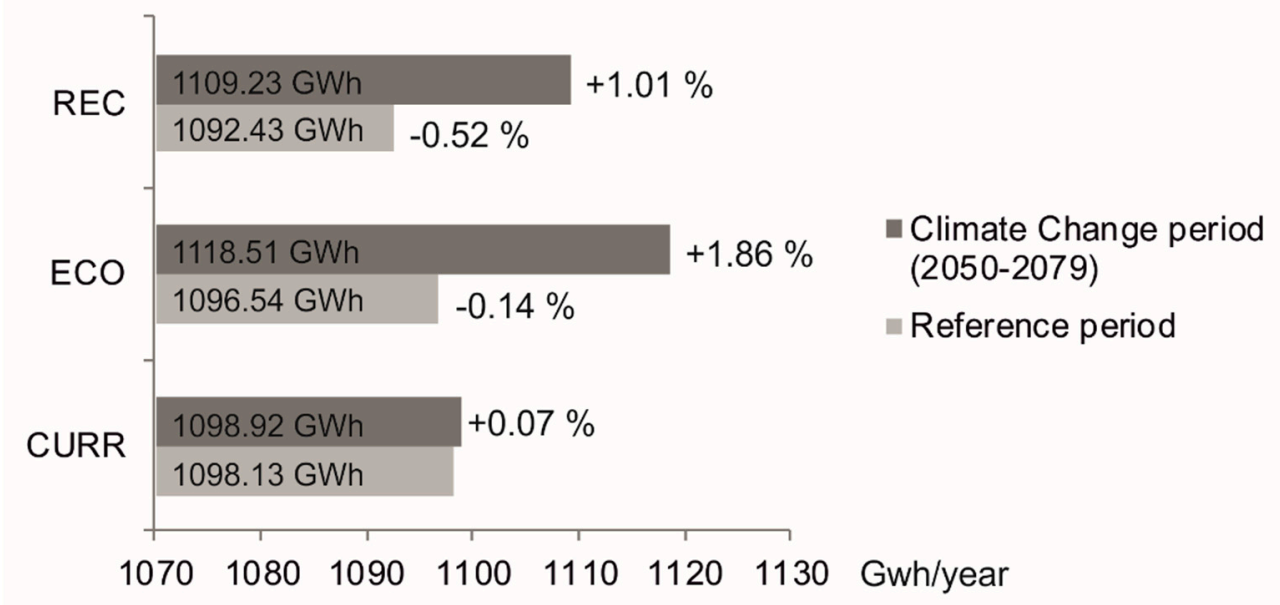

Figure 10. The energy production capacity (in GWh/a) of the control period and climate change period with different regulation alternatives. The values were calculated and applied in the study by Dubrovin et al. [51]. The difference of each case compared to the reference period with the current regulation rules (R CURR) is marked in the figure in percent. Note that the x-axis starts from $1070 \mathrm{GWh} / \mathrm{a}$.

\subsection{Uncertainties in the Methodological Approach}

There are several issues in the methodological approach applied in this study, which affect the results and cause uncertainties, and which the reader should be aware of. These include the choice of the emission and climate scenario, the single hydrological scenario used for further analysis, the method used to transfer the climate signal to the hydrological model and the hydrological model structure and parameters [21,24]. In addition, the choice of the regulation options and their estimated impacts on ecology and recreation, as well as the hydrodynamic model, contain uncertainties.

The climate scenarios, applied in this study, are based on regional climate model data from the ENSEMBLEs data archive [77]. These data use SRES (Special Report on Emission Scenario) A1B scenario [89] The ENSEMBLES data were used since they were available at the time when the hydrological modeling work began, several years ago. Since then, RCM data from EURO-CORDEX using RCP (Representative Concentration Pathway [90]) scenarios have become available [91]. The main differences between these data are different emission scenarios, higher resolution $\left(0.11^{\circ}\right.$ in EURO-CORDEX and $0.25^{\circ}$ in ENSEMBLES) and in part newer versions of the RCMs and/or GCMs [91]. However, the higher resolution brings the greatest improvements in regions with substantial topographical variability [92], and therefore in the flat Kokemäenjoki watershed (elevations $\sim 0-200 \mathrm{~m}$ ) the impact was considered minor. Furthermore, based on the study by Ruosteenoja et al. [56] there are only minor differences between the climate change predictions in Finland based on RCP and SRES emission scenarios and those differences are mostly in the summer temperatures. The range for temperature and precipitation change in 2050-2079 (from 1985-2014) with the seven RCM scenarios with A1B used in this study was $1.6-3.5^{\circ} \mathrm{C}$ and $-1.1-13.5 \%$, respectively (Table 2). The range of ensemble means of the four RCP scenarios in 2050-2079 provided by Ruosteenoja et al. [56] (with reference period $1981-2010$ ) are $1.9-4.0^{\circ} \mathrm{C}$ for temperature and $6-13 \%$ for precipitation. The range of the climate scenarios we used is therefore rather similar to the range with ensemble means of the different RCP scenarios. For this study, we selected for further analysis one climate scenario, which was considered to represent the average projection from the range of scenarios. In 2050-2079, this average scenario corresponds rather well to the mean of RCP scenarios 4.5 and 6.0 [56]. The use of one climate scenario means that the uncertainties of climate change are not modeled in the CDF analysis and the possible range of changes in fluvial forces and inundated areas is larger than projected by our results. 
The delta change approach was used to transfer the monthly changes in temperature and precipitation to the hydrological model. This method capability to estimate floods has been criticized, since it does not take into account changes in distributions and hence different changes in extreme precipitation [44,79]. However, in this study, we investigated an average high flow event, which is not very extreme. Additionally, the properties of the watershed with large area and many lakes means that the flood events are not typically produced by a single precipitation event, but rather by snowmelt or prolonged periods of heavy precipitation. The direction of changes in floods in Finland with the delta change method and other methods have been found to be mostly similar [24]. Therefore, the delta change method is likely to provide adequate results for this study.

Further uncertainties for the methodological approach brings the cascade of the different simulations, because of the non-linearity of the climatic, hydrological and geomorphic systems [93,94]. The climate model, together with the applied emission scenario, affects the air temperature and precipitation results. These temperature and precipitation further impact on the hydrological model's discharge and water level outputs, which are also affected by the hydrological model structure and parameter uncertainties. Modeling of each regulation strategy also involves uncertainty: the same set of regulation rules, which is applied every year, is not able to regulate all individual years optimally.

The errors originating from hydrodynamic modeling are mainly related to the quality of the initial and boundary conditions, and the spatial resolution, accuracy, and precision of the topographic and bathymetric data. In addition, the model resolution affects the level of detail. To assess the hydrodynamic model performance, we performed four validation runs with different flow conditions. The mean error of the four validation runs at the calibration data point was $0.045 \mathrm{~m}$ and the maximum error was $0.07 \mathrm{~m}$. Considering the relatively low grid resolution (5-15 $\mathrm{m}$ in the channel), and the point density of $10 \mathrm{~m}$ in the original topographical data (which resulted in an average absolute error of $0.29 \mathrm{~m}$ due to interpolation into the computational grid), the model performance was considered adequate in the validation process. Errors caused by the hydrodynamic modeling may have an effect, especially on the inundation area on the flat terrain. However, the effect of error should not be significant, when investigating the relative differences of the high flow events in the reference period and future. In addition, some of these uncertainties produced by the previous simulation steps propagates also to the CFD analyses, where the discharge is applied as the input value of the upstream boundary. However, the uncertainties in climate change impacts are not modeled in the CDF analysis, since results from only the average scenario are used.

In this study, we tried to minimize these cascading uncertainties with the detailed possible calibration of each model applied. In hydrological climate change impact assessments, the uncertainties from choice of GCM are usually found to be larger than uncertainties from hydrological model structure or parameters [21]. Since the uncertainties and the propagation of uncertainties remain large, the decision makers should be made aware of these uncertainties.

\section{Conclusions}

In this study, we investigated how the predicted hydro-climatological changes will affect the distribution of fluvial forces and inundated area during $\mathrm{MHQ}$, and how adaptive regulation standards could attenuate the climate change impacts in a low-relief river of the Southern Boreal climate area, Southwestern Finland. With hydrologically modeled future flow conditions as initial data, we used hydraulic modeling (Delft 3D FM) to compare the projected future (2050-2079) erosion and inundation area during MHQ events with the corresponding events of the control period (1985-2014). The future flow conditions were modeled with the current regulation rules (CURR), as well as with adaptive regulation standards with different emphases: a strategy favoring ecologically sustainable lake water levels (ECO) and a strategy supporting the recreational usage of the lakes (REC).

The expected hydro-climatological changes of the Southern Boreal area, such as an increase in runoff and peak discharges, especially in wintertime, will have a direct impact on high flow events in the low-relief study area. Even though the mean flow depth will not increase notably (from $1.14 \mathrm{~m}$ to 
$1.25 \mathrm{~m}$ ) during an MHQ flow compared to the control period, the inundated area will expand by $15 \%$. In our study area, the relative sea level will not increase in the near future due to the compensating effect of isostatic land uplift. However, occasional high water levels are expected due to increasing weather extremes. Thus, if a high water level occurs concurrently with the MHQ discharge, the inundated area will increase $30 \%$ in the future compared to the control period. The high flow situations may be restrained by enhanced regulation rules. The ECO strategy will diminish the discharge and inundation area more than the REC strategy. The inundated area during an MHQ discharge in the climate change period will increase only $10 \%$ compared to the control period if the ECO strategy is used. However, climate change will increase the runoff and MHQ discharges, as well as water levels in the area, and the proposed regulation changes are not able to eliminate this. Additionally, the expected changes in sea level extremes, such as weather-induced events, may affect flooding and should be considered in flood protection before the long-term mean sea level rise actualizes.

Despite the increase in discharges and inundation areas, the erosional power during a MHQ discharge will decrease in the near future, with even larger differences from the control period if a high water level event is considered. This is due to the changes in timing of floods more from spring to autumn and winter, when the average sea level during the flood is higher. The enhanced regulation rules (ECO and REC) do not have much influence on the erosional power, but a minor decrease is expected with the ECO strategy compared to the CURR strategy. Thus, our results indicate that climate change and the enhanced regulation rules could provide some adaption in terms of erosion, but further research is needed on the longer-term effects of different regulation rules.

The hydropower production will benefit from the increased runoff. Of each alternative regulation strategy, the ecologically sustainable one would enable the highest energy production and restrain most the increase in flooding in the future. Based on the simulations, the demands of environment, society, and hydropower generation are not necessarily contradictory, and, presumably, regulation will provide an important adaptive practice in the future, especially in terms of increasing high flow events of the Southern Boreal climate area.

Author Contributions: E.K., funding acquisition, project administration, analysis, data collection, methodology, analysis, visualization, and writing; E.L., funding acquisition, data collection, and writing; M.K., methodology, modeling, and writing; T.D., methodology, modeling, and writing; and N.V., methodology, modeling, and writing.

Funding: This study was funded by the Academy of Finland (InfraRiver project, grant number 296090; COMBAT project, grant number 293389; and Centre of Excellence in Laser Scanning Research, grant numbers 307362 and 292735), Emil Aaltonen foundation, the Department of Geographical and Historical Studies of the University of Eastern Finland, Finnish Environment Institute, ELY Centres of Finland and the Ministry of Agriculture and Forestry of Finland.

Conflicts of Interest: The authors declare no conflict of interest. The funders had no role in the design of the study; in the collection, analyses, or interpretation of data; in the writing of the manuscript, or in the decision to publish the results.

\section{References}

1. McCully, P. Silenced Rivers; Zed Books: London, UK, 1996.

2. Nilsson, C.; Berggen, K. Alterations of riparian ecosystems caused by river regulation. Bioscience 2000, 50, 783. [CrossRef]

3. Petts, G.E. Impounded Rivers; John Wiley \& Sons: Chichester, UK, 1984.

4. Shields, F.D.; Simon, A.; Steffen, L.J. Reservoir effects on downstream river channel migration. Environ. Conserv. 2000, 27, 54-66. [CrossRef]

5. Church, M. Geomorphic response to river flow regulation: Case studies and time-scales. Regul. Rivers Res. Manag. 1995, 11, 3-22. [CrossRef]

6. Draut, A.E.; Logan, J.B.; Mastin, M.C. Channel evolution on the dammed Elwha River, Washington, USA. Geomorpgology 2011, 127, 71-87. [CrossRef]

7. Fergus, T. Geomorphological response of a river regulated for hydropower: River Fortun, Norway. River Res. Appl. 1997, 13, 449-461. [CrossRef] 
8. Grams, P.E.; Schmidt, J.C.; Topping, D.J. The rate and pattern of bed incision and bank adjustment on the Colorado River in Glen Canyon downstream from Glen Canyon Dam, 1956-2000. Geol. Soc. Am. Bull. 2007, 119, 556-575. [CrossRef]

9. Kondolf, G.M.; Gao, Y.; Annandale, G.W.; Morris, G.L.; Jlang, E.; Zhang, J.; Cao, Y.; Carling, P.; Fu, K.; Guo, Q.; et al. Sustainable sediment management in reservoirsand regulated rivers: Experiences from five continents. Earth Future 2014, 2, 256-280. [CrossRef]

10. Ma, Y.; Huang, H.Q.; Nanson, G.C.; Li, Y.; Yao, W. Channel adjustments in response to the operation of large dams: The upper reach of the lower Yellow River. Geomorpgology 2012, 147, 35-48. [CrossRef]

11. Mosley, M.P. Analysis of the effect of changing discharge on channel morphology and instream uses in a Braided River, Ohau River, New Zealand. Water Resour. Res. 1982, 18, 800-812. [CrossRef]

12. Petts, G.E. Complex response of river channel morphology subsequent to reservoir construction. Prog. Phys. Geogr. 1979, 3, 329. [CrossRef]

13. Nilsson, C.; Reidy, C.A.; Dysenius, M.; Revenga, C. Fragmentation and flow regulation of the world's large river systems. Science 2005, 308, 405-408. [CrossRef]

14. Heggens, J.; Alfredsen, K.; Bustos, A.A.; Huusko, A.; Stickler, M. Be cool: A review of hydro-physical changes and fish responses in winter in hydropower-regulated northern streams. Environ. Biol. Fishes 2018, 101, 1-21. [CrossRef]

15. Rădoane, M.; Ciaglic, V.; Rădoane, N. Hydropower impact on the ice jam formation on the upper Bistrita River, Romania. Cold Reg. Sci. Technol. 2010, 60, 193-204. [CrossRef]

16. Berga, L. The Role of Hydropower in climate change mitigation and adaptation: A Review. Engineering 2016, 2, 313-318. [CrossRef]

17. Hamududu, B.; Killingtveit, A. Assessing climate change impacts on global hydropower. Energies 2012, 5, 305-322. [CrossRef]

18. Barnett, T.P.; Adam, J.C.; Lettenmaier, D.P. Potential impacts of a warming climate on water availability in snow-dominated regions. Nature 2005, 438, 303. [CrossRef]

19. Thodsen, H.; Hashol, T.B.; Kjærsgaard, J.H. The influence of climate change on suspended sediment transport in Danish rivers. Hydrol. Process. 2008, 22, 764-774. [CrossRef]

20. Verhaar, P.M.; Biron, P.M.; Ferguson, R.I.; Hoey, T.B. Numerical modelling of climate change impacts on Saint-Lawrence River tributaries. Earth Surf. Process. Landf. 2010, 35, 1184-1198. [CrossRef]

21. Kay, A.L.; Davies, H.N.; Bell, V.A.; Jones, R.G. Comparison of uncertainty sources for climate change impacts: Flood frequency in England. Clim. Chang. 2009, 92, 41-63. [CrossRef]

22. Markoff, M.S.; Cullen, A.C. Impact of climate change on pacific Northwest hydropower. Clim. Chang. 2008, 87, 469. [CrossRef]

23. Shen, M.; Chen, J.; Zhuan, M.; Chen, H.; Xu, C.-Y.; Xiong, L. Estimating uncertainty and its temporal variation related to global climate models in quantifying climate change impacts on hydrology. J. Hydrol. 2018, 556, 10-24. [CrossRef]

24. Veijalainen, N. Estimation of Climate Change Impacts on Hydrology and Floods in FINLAND; Aalto University: Espoo, Finland, 2012; ISBN 978-952-60-4614-3.

25. Johansson, M.M.; Kahma, K.K.; Boman, H.; Launiainen, J. Scenarios for sea level on the Finnish coast. Boreal Environ. Res. 2004, 9, 153-166.

26. Miettinen, A.; Jansson, H.; Alenius, T.; Haggrén, G. Late Holocene sea-level changes along the southern coast of Finland, Baltic Sea. Mar. Geol. 2007, 242, 27-38. [CrossRef]

27. Ojala, E.; Louekari, S. The merging of human activity and natural change: Temporal and spatial scales of ecological change in the Kokemäenjoki river delta, SW Finland. Landsc. Urban Plan. 2002, 61, 83-98. [CrossRef]

28. Kingsford, R.T. Ecological impacts of dams, water diversions and river management on floodplain wetlands in Australia. Austral Ecol. 2000, 25, 109-127. [CrossRef]

29. Yang, G.; Guo, S.; Li, L.; Hong, X.; Wang, L. Multi-Objective Operating Rules for Danjiangkou Reservoir Under Climate Change. Water Resour. Manag. 2016, 30, 1183-1202. [CrossRef]

30. Zarfl, C.; Lumsdon, A.E.; Berlekamp, J.; Tydecks, L.; Tockner, K. A global boom in hydropower dam construction. Aquat. Sci. 2015, 77, 161-170. [CrossRef]

31. Veijalainen, N.; Lotsari, E.; Alho, P.; Vehviläinen, B.; Käyhkö, J. National scale assessment of climate change impacts on flooding in Finland. J. Hydrol. 2010, 391, 333-350. [CrossRef] 
32. Humborg, C.; Ittekkot, V.; Cociasu, A.; VonBodungen, B. Effect of Danube River dam on Black Sea biogeochemistry and ecosystem structure. Nature 1997, 386, 385. [CrossRef]

33. Palmer, M.A.; Liermann, C.A.R.; Nilsson, C.; Flörke, M.; Alcamo, J.; Lake, P.S.; Bond, N. Climate change and the world's river basins: Anticipating management options. Front. Ecol. Environ. 2008, 6, 81-89. [CrossRef]

34. Amin, M.Z.M.; Shaaban, A.J.; Ercan, A.; Ishida, K.; Kavvas, M.L.; Chen, Z.Q.; Jang, S. Future climate change impact assessment of watershed scale hydrologic processes in Peninsular Malaysia by a regional climate model coupled with a physically-based hydrology modelo. Sci. Total Environ. 2017, 575, 12-22. [CrossRef]

35. Andréasson, J.; Bergström, S.; Carlsson, B.; Graham, L.P.; Lindström, G. Hydrological Change-Climate Change Impact Simulations for Sweden. AMBIO A J. Hum. Environ. 2004, 33, 228-234. [CrossRef]

36. Beldring, S.; Engen-Skaugen, T.; Førland, E.J.; Roald, L.A. Climate change impacts on hydrological processes in Norway based on two methods for transferring regional climate model results to meteorological station sites. Tellus A Dyn. Meteorol. Oceanogr. 2008, 60,439-450. [CrossRef]

37. Chaminé, H.I.; Barbieri, M.; Kisi, O.; Chen, M.; Merkel, B.J. (Eds.) Advances in Sustainable and Environmental Hydrology, Hydrogeology, Hydrochemistry and Water Resources: Proceedings of the 1st Springer Conference of the Arabian Journal of Geosciences (CAJG-1), Tunisia 2018; Advances in Science, Technology \& Innovation; Springer International Publishing: Cham, Switzerland, 2019; ISBN 978-3-030-01571-8.

38. Hattermann, F.F.; Krysanova, V.; Gosling, S.N.; Dankers, R.; Daggupati, P.; Donnelly, C.; Flörke, M.; Huang, S.; Motovilov, Y.; Buda, S.; et al. Cross-scale intercomparison of climate change impacts simulated by regional and global hydrological models in eleven large river basins. Clim. Chang. 2017, 141, 561-576. [CrossRef]

39. Olsson, T.; Jakkila, J.; Veijalainen, N.; Backman, L.; Kaurola, J.; Vehviläinen, B. Impacts of climate change on temperature, precipitation and hydrology in Finland-Studies using bias corrected Regional Climate Model data. Hydrol. Earth Syst. Sci. Katlenburg Lindau 2015, 19, 3217-3238. [CrossRef]

40. Majone, B.; Villa, F.; Deidda, R.; Bellin, A. Impact of climate change andwater use policies on hydropower potential in the south-eastern Alpine region. Sci. Total Environ. 2016, 543, 965-980. [CrossRef]

41. Cherry, J.E.; Knapp, C.; Trainor, S.; Ray, A.J.; Tedesche, M.; Walker, S. Planning for climate change impacts on hydropower in the Far North. Hydrol. Earth Syst. Sci. Katlenburg Lindau 2017, 21, 133-151. [CrossRef]

42. Bergström, S.; Carlsson, B.; Gardelin, M.; Lindström, G.; Pettersson, A.; Rummukainen, M. Climate change impacts on runoff in Sweden-Assessments by global climate models, dynamical downscaling and hydrological modelling. Clim. Res. 2001, 16, 101-112. [CrossRef]

43. Chernet, H.H.; Alfredsen, K.; Killingtveit, Å. The impacts of climate change on a Norwegian high-head hydropower system. J. Water Clim. Chang. 2013, 4, 17-37. [CrossRef]

44. Graham, L.P.; Andreasson, J.; Carlsson, B. Assessing climate change impacts on hydrology from an ensemble of regional climate models, model scales and linking methods-A case study on the Lule River basin. Clim. Chang. 2007, 81, 293-307. [CrossRef]

45. Wright, R.F.; Couture, R.-M.; Christiansen, A.B.; Guerrero, J.-L.; Kaste, Ø.; Barlaup, B.T. Effects of multiple stresses hydropower, acid deposition and climate change on water chemistry and salmon populations in the River Otra, Norway. Sci. Total Environ. 2017, 574, 128-138. [CrossRef]

46. Ettema, R. Review of alluvial-channel responses to river ice. J. Cold Reg. Eng. 2002, 16, 191. [CrossRef]

47. Kämäri, M.; Alho, P.; Veijalainen, N.; Aaltonen, J.; Huokuna, M.; Lotsari, E. River ice cover influence on sediment transportation at present and under projected hydroclimatic conditions. Hydrol. Process. 2015, 29, 4738-4755. [CrossRef]

48. Julian, J.P.; Torres, R. Hydraulic erosion of cohesive riverbanks. Geomorphology 2006, 76, 193-206. [CrossRef]

49. Lotsari, E.; Wainwright, D.; Corner, G.D.; Alho, P.; Käyhkö, J. Surveyed and modelled one-year morphodynamics in the braided lower Tana River. Hydrol. Process. 2014, 28, 2685-2716. [CrossRef]

50. Wolman, M.G. Factors Influencing Erosion of a Cohesive River Bank. Am. J. Sci. 1959, 257, $204-216$. [CrossRef]

51. Dubrovin, T.; Isid, D.; Kumpumäki, M.; Mustajoki, J.; Jakkila, J.; Marttunen, M. Kehittämissuositukset Pirkanmaan Keskeisten Järvien Säännöstelyille. ELY-keskuksen Raportteja 2017, 26, 110.

52. Peel, M.C.; Finlayson, B.L.; McMahon, T.A. Updated world map of the Köppen-Geiger climate classification. Hydrol. Earth Syst. Sci. 2007, 11, 1633-1644. [CrossRef]

53. Graham, L.P. Climate change effects on river flow to the Baltic Sea. A J. Hum. Environ. 2004, 33, $235-241$. [CrossRef] 
54. Madsen, H.; Lawrence, D.; Lang, M.; Martinkova, M.; Kjeldsen, T.R. Review of trend analysis and climate change projections of extreme precipitation and floods in Europe. J. Hydrol. 2014, 519, 3634-3650. [CrossRef]

55. Korhonen, J. Long-term Changes and Variability of the Winter and Spring Season Hydrological Regime in Finland; University of Helsinki: Helsinki, Finland, 2019; ISBN 978-951-51-2800-3.

56. Ruosteenoja, K.; Jylhä, K.; Kämäräinen, M. Climate Projections for Finland Under the RCP Forcing Scenarios. Geophysica 2016, 51, 17-50.

57. IPCC Global Warming of $1.5^{\circ} \mathrm{C}$. Available online: https://www.ipcc.ch/sr15/ (accessed on 1 August 2019).

58. Lawrence, D.; Haddeland, I. Uncertainty in hydrological modelling of climate change impacts in four Norwegian catchments. Hydrol. Res. 2011, 42, 457-471. [CrossRef]

59. Lotsari, E.; Aaltonen, J.; Veijalainen, N.; Alho, P.; Käyhkö, J. Future fluvial erosion and sedimentation potential of cohesive sediments in a coastal river reach of SW Finland. Hydrol. Process. 2014, 28, 6016-6037. [CrossRef]

60. IPCC Summary for Policymakers. In Climate Change 2013: The Physical Science Basis. Contribution of Working Group I to the Fifth Assessment Report of the Intergovernmental Panel on Climate Change; Stocker, T.F.; Qin, D.; Plattner, G.-K.; Tignor, M.; Allen, S.K.; Boschung, J.; Nauels, A.; Xia, Y.; Bex, V.; Midgley, P.M. (Eds.) Cambridge University Press: Cambridge, UK; New York, NY, USA, 2013; pp. 1-30. ISBN 978-1-107-66182-0.

61. Helcom Baltic Compass-Helcom. Available online: http://www.helcom.fi/helcom-at-work/projects/ completed-projects/baltic-compass (accessed on 11 September 2018).

62. Johansson, M.M.; Pellikka, H.; Kahma, K.K.; Ruosteenoja, K. Global sea level rise scenarios adapted to the Finnish coast. J. Mar. Syst. 2014, 129, 35-46. [CrossRef]

63. Pellikka, H.; Leijala, U.; Johansson, M.M.; Leinonen, K.; Kahma, K.K. Future probabilities of coastal floods in Finland. Cont. Shelf Res. 2018, 157, 32-42. [CrossRef]

64. Koskinen, M. Porin Tulvat—Halittuja Riskejä; Suomen Ympäristö: Kokemäki, Finland, 2006; p. 84.

65. Vainio, M. Flood Protection Action Plan for Kokemäenjoki Watershed; Alueelliset ympäristöjulkaisut: Tampere, Finland, 1999; p. 83.

66. Kersalo, J.; Pirinen, P. Suomen Maakuntien Ilmasto; Reports; Finnish Meteorological Institute: Helsinki, Finland, 2009; p. 192.

67. Pirinen, P.; Simola, H.; Aalto, J.; Kaukoranta, J.-P.; Karlsson, P.; Ruuhela, R. Tilastpja Suomen Ilmastosta 1981-2010; Ilmatieteenlaitoksen Raportteja; Ilmatieteen Laitos: Helsinki, Finland, 2012; ISBN 978-951-697-765-5.

68. Alho, P.; Sane, M.; Huokuna, M.; Käyhkö, J.; Lotsari, E.; Lehtiö, L. Mapping of Flood Risks Petteri Alho, Mikko Sane, Mikko Huokuna, Jukka Käyhkö, Eliisa Lotsari Ja Laura Lehtiö; Ympäristöhallinnon ohjeita; Finnish Environmental Institute: Helsinki, Finland, 2008.

69. Aulio, K. Kokemäenjoki River Delta, Western Finland-Natural Treasury in an Exceptionally Rapidly Changing Aquatic Environment. Int. Lett. Nat. Sci. 2015, 32, 36-53.

70. Finnish Environment Institute. Available online: https://www.syke.fi/en-US/Open_information/Open_web_ services/Environmental_data_API (accessed on 13 July 2019).

71. VARELY. Kokemäenjoen Vesistöalueen Tulvariskien Hallintasuunnitelma Vuosille 2016-2021; Varsinais-Suomen ELY-keskus Raportteja; Centre for Economic Development, Transport and the Environment of the Southwest Finland: Turku, Finland, 2015; p. 178.

72. Dubrovin, T.; Jakkila, J.; Aaltonen, J.; Kumpumäki, M.; Vehviläinen, B. Kokemäenjoen Vesistöalueen PadotusJa Juoksutusselvitys. 2017. Available online: https://docplayer.fi/57099716-Suomen-ymparistokeskus.html (accessed on 26 October 2018).

73. Vehviläinen, B.; Huttunen, M. Hydrological Forecasting and Real Time Monitoring in Finland: The Watershed Simulation and Forecasting System (WSFS); Suomen Ympäristökeskus: Helsinki, Finland, 2001.

74. Aaltonen, J.; Veijalainen, N.; Huokuna, M. The effect of climate chance on frazil ice jam formation in the Kokemäenjoki River. In Proceedings of the 20th IAHR International Symposium on Ice, Lahti, Finland, 14-18 June 2010.

75. Prudhomme, C.; Jakob, D.; Svensson, C. Uncertainty and climate change impact on the flood regime of small UK catchments. J. Hydrol. 2003, 277, 1-23. [CrossRef]

76. Veijalainen, N.; Jakkila, J.; Nurmi, T.; Vehviläinen, B.; Marttunen, M.; Aaltonen, J. Suomen Vesivarat Ja Ilmastonmuutos-Vaikutukset Ja Muutoksiin Sopeutuminen. WaterAdapt-Projektin Loppuraportti; Suomen ympäristökeskus: Helsinki, Finland, 2012; ISBN 978-952-11-4018-1. 
77. Van der Linden, P.; Mitchell, J.F.B. ENSEMBLES: Climate Change and its Impacts: Summary of Research and Results from the ENSEMBLES Project; Met Office Hadley Centre: Exeter, UK, 2009.

78. Taylor, K.E.; Stouffer, R.J.; Meehl, G.A. An overview of CMIP5 and the experiment design. Bull. Amer. Meteor. Soc. 2012, 93, 485-498. [CrossRef]

79. Veijalainen, N.; Jakkila, J.; Nurmi, T.; Vehviläinen, B.; Marttunen, M.; Aaltonen, J. Suomen Vesivarat Ja Ilmastonmuutos—Vaikutukset Ja Muutoksiin Sopeutuminen; Suomen Ympäristö; Finnish Environmental Institute: Helsinki, Finland, 2012; p. 138.

80. Keto, A.; Tarvainen, A.; Marttunen, M.; Hellsten, S. Use of the water-level fluctuation analysis tool (Regcel) in hydrological status assessment of finnish lakes. In Ecological Effects of Water-Level Fluctuations in Lakes; Wantzen, K.M., Rothhaupt, K.-O., Mörtl, M., Cantonati, M., Tóth, L.G., Fischer, P., Eds.; Springer: Dordrecht, The Netherlands, 2008; pp. 133-142. ISBN 978-1-4020-9191-9.

81. Marttunen, M.; Nieminen, H.; Keto, A.; Suomalainen, M.; Tarvainen, A.; Moilanen, S.; Järvinen, E.A. Pirkanmaan Keskeisten Järvien Säännöstelyjen Kehittäminen. Yhteenveto ja Suositukset; Suomen ympäristö; Finnish Environmental Institute: Helsinki, Finland, 2004; p. 195.

82. Son, T. RiverSurveyor S5/M9 System Manual, Firmware Version 3.50; AonTek, a Xylem Brand: San Diego, CA, USA, 2013.

83. Leendertse, J.J. A Three-Dimensional Alternating Direction Implicit Model with Iterative Fourth Order Dissipative Non-linear Advection Terms; WD-3333-NETH; Rijkswaterstaat: The Hague, The Netherlands, 1987.

84. Stelling, G.; Leendertse, J. Approximation of Convective Processes by Cyclic AOI Methods. In Estuarine and Coastal Modelling; Spaulding, M.L., Bedford, K., Blumberg, A., Cheng, R., Swanson, C., Eds.; American Society of Civil Engineers: New York, NY, USA, 1992; pp. 771-782.

85. Kasvi, E.; Alho, P.; Lotsari, E.; Wang, Y.; Kukko, A.; Hyyppä, H.; Hyyppä, J. Two-dimensional and three-dimensional computational models in hydrodynamic and morphodynamic reconstructions of a river bend: sensitivity and functionality. Hydrol. Process. 2015, 29, 1604-1629. [CrossRef]

86. Deltares D-Flow Flexible Mesh, User Manual. Available online: https://oss.deltares.nl/web/delft3dfm/manuals (accessed on 1 September 2019).

87. Bathurst, J.C.; Hey, R.D.; Thorne, C.R. Secondary flow and shear stress at river bends. J. Hydraul. Div. 1979, 105, 1277-1295.

88. Shields, A. Anwendung Der Ähnlickeit Mechanik under Turbulenzforschung Auf Die Geschiebelerwegung. Mitt. Preuss Versuchanstalt Fur Wasserbau und Schiffbau. Ph.D. Thesis, Mitt. Preuss Versuchanstalt fur Wasserbau und Schiffbau, Berlin, Germany, 1936.

89. Nakicenovic, N.; Alcamo, J.; Grubler, A.; Riahi, K.; Roehrl, R.A.; Rogner, H.-H.; Victor, N. Special Report on Emissions Scenarios (SRES), A Special Report of Working Group III of the Intergovernmental Panel on Climate Change; Cambridge University Press: Cambridge, UK, 2000; ISBN 978-0-521-80493-6.

90. van Vuuren, D.P.; Edmonds, J.; Kainuma, M.; Riahi, K.; Thomson, A.; Hibbard, K.; Hurtt, G.C.; Kram, T.; Krey, V.; Lamarque, J.-F.; et al. The representative concentration pathways: An overview. Clim. Chang. 2011, 109, 5. [CrossRef]

91. Jacob, D.; Petersen, J.; Eggert, B.; Alias, A.; Christensen, O.B.; Bouwer, L.M.; Braun, A.; Colette, A.; Déqué, M.; Georgievski, G.; et al. EURO-CORDEX: new high-resolution climate change projections for European impact research. Reg. Environ. Chang. 2014, 14, 563-578. [CrossRef]

92. Prein, A.F.; Gobiet, A.; Truhetz, H.; Keuler, K.; Goergen, K.; Teichmann, C.; Maule, C.F.; van Meijgaard, E.; Déqué, M.; Nikulin, G.; et al. Precipitation in the EURO-CORDEX $0.11^{\circ}$ and $0.44^{\circ}$ simulations: high resolution, high benefits? Clim. Dyn. 2016, 46, 383-412. [CrossRef]

93. Lotsari, E.; Thorndycraft, V.; Alho, P. Prospects and challenges of simulating river channel response to future climate change. Prog. Phys. Geogr. 2015, 39, 483-513. [CrossRef]

94. Coulthard, T.J.; Ramirez, J.; Fowler, H.J.; Glenis, V. Using the UKCP09 probabilistic scenarios to model the amplified impact of climate change on drainage basin sediment yield. Hydrol. Earth Syst. Sci. 2012, 16, 4401-4416. [CrossRef]

(C) 2019 by the authors. Licensee MDPI, Basel, Switzerland. This article is an open access article distributed under the terms and conditions of the Creative Commons Attribution (CC BY) license (http://creativecommons.org/licenses/by/4.0/). 